\title{
THE STRUCTURE AND HistORY OF ITALIAN UNEMPLOYMENT
}

\author{
GIUSEPPE BERTOLA \\ PIETRO GARIBALDI
}

CESIFO WORKING PAPER NO. 907

CATEGORY 4: LABOUR MARKETS

APRIL 2003

Presented at CESifo Conference on Unemployment in Europe,

December 2002

\footnotetext{
An electronic version of the paper may be downloaded

- from the SSRN website: $\quad$ www.SSRN.com

- from the CESifo website: www.CESifo.de
} 


\title{
THE STRUCTURE AND HistORY OF ITALIAN UNEMPLOYMENT
}

\begin{abstract}
This paper reviews the Italian unemployment experience, analyzing in particular the timeseries behavior of unemployment rates along the path that brought Italy into Europe's Economic and Monetary Union, and their disaggregated structure across geographical and demographic dimensions. High aggregate unemployment is a reflection of highly concentrated unemployment, especially along geographical dimensions but also among relatively young workers. Its evolution resulted historically from well-understood interactions of macroeconomic events and institutional configurations. We also review recent developments and reform tensions.
\end{abstract}

JEL Code: J2.

Giuseppe Bertola Department of Economics

European University Institute

Via Piazzola 43

I-50133 San Domenico di Fiesole (FI)

Italy

bertola@iue.it
Pietro Garibaldi

Bocconi University

Via Sarfatti 25

20136 Milano

Italy

pietro.garibaldi@uni-bocconi.it

We thank Saverio Scaramuzzo for competent research assistance. 


\section{Introduction}

This paper reviews the Italian unemployment experience, analyzing in particular the time-series behavior of unemployment rates along the path that brought Italy into Europe's Economic and Monetary Union, and their disaggregated structure across geographical and demographic dimensions. It purposely refrains from cross-country comparisons. It will be useful, however, to refer to recent panel studies when interpreting the institutional information and empirical evidence we collect and report.

Across countries, the relative dynamics of labor market institutions did not mirror overall unemployment dynamics. In the 1960s and early 1970s rather pronounced differences in labor market institutions were consistent with lower unemployment in Europe than in the US. While institutions did evolve (albeit slowly and haltingly) within each country, the qualitative character of reforms was largely similar. As a result, changes of labor market institutions were broadly synchronized. A wave of rigidityoriented institutional revisions in the late 1960 and 1970s was followed by partial and intermittent liberalization in the 1980s and 1990s (the United Kingdom's earlier transition to a deregulated labor market being, of course, the exception to this broad trend). To the extent that employment protection legislation, wage bargaining institutions, and other relevant features not only evolved slowly, but remained consistently different across countries, in order to explain the widely divergent unemployment experience of otherwise similar countries one needs to allow for differential impact of time-series macroeconomic developments on cross-sectionally different institutional environments. As pointed out by Blanchard and Wolfers (2000), macroeconomic shocks were largely common across countries. Productivity growth slowed down across all industrial countries in the early 1970s, and oil price increased in the 1970s and early 1980s. In the 1980s and 1990s, globalization and technological change reduced demand for unskilled labor and stability-oriented macroeconomic policies were implemented by most OECD countries, which experienced large falls in inflation during the last few decades. Unemployment rates remained low in labor markets where such developments could be accommodate by changes in absolute and relative real wages, but surged where negative labor demand shocks were faced by high, rising, and compressed real wages.

This approach can be fruitfully brought to bear on unemployment developments within Italy. As discussed in more detail below, the range of unemployment rates across Italian regions is very wide, indeed just about as wide as that observed across regions over all the European Union and across all OECD countries. And unemployment rates across Italian regions (just like unemployment rates across countries in standard panel studies) fanned out over time, with unemployment rising fast in some regions and fluctuating along a stable level in other regions. To the extent that these regional unemployment dynamics can be traced back to nationwide developments, shocks-institution interactions are as important within Italy as across the OECD: institutional constraints had increasingly adverse effects in the former regions, and remained consistent with near-full employment in the latter.

The theoretical perspective of standard cross-country panel regressions is also useful when interpreting the role of shocks and institutions in shaping the time-series history of Italian unemployment and employment rates. When considering an individual country, however, it is possible to draw on a larger information base regarding the dynamic development of labor market institutions and disaggregated unemployment outcomes. To the extent that reforms and outcomes interact through endogenous channels, it would be difficult and potentially misleading to estimate time-series relationships between slowly evolving institutions and labor market outcomes influenced by forwardlooking behavior by workers and firms. However, guidance from existing panel studies makes it possible to assess the extent to which standard explanatory mechanisms are applicable to Italy, both over time and across disaggregated dimensions. 
The paper proceeds as follows. Section 2 presents the main facts on the evolution of Italian unemployment, with a focus on both regional and age dimensions. Section 3 presents the institutional framework, aiming at presenting a complete if abbreviated picture of collective bargaining arrangements, employment protection legislation, and active and passive labor market policies. Section 4 aims at interpreting the historical evolution as the natural outcome of the combination of adverse macroeconomic interacting with the complex institutional framework described in Section 3. Section 5 reviews recent developments, and concludes.

\section{Facts}

This section reviews a set of stylized facts on Italian unemployment over the last thirty years, focusing on the large and persistent regional and age unemployment differentials. Firstly, we look at the historical evolution of the aggregate unemployment rate. Next, we define the main structural characteristics of unemployment, and analyze them cross-sectionally and over time. Throughout this section we just report key unemployment statistics and stylized facts, postponing most assessment and interpretation.

\subsection{The evolution of the aggregate unemployment rate}

"Unemployed" individuals are those who are willing to work at the going wage, yet unable to find a job. Willingness to work is a well-defined notion in principle but, of course, its measurement has to rely on the design of labor force surveys and on the interpretation of respondents' answers. As currently defined, the Italian unemployment rate stood at 9.1 percent of the labor force in December 2001. Recent years saw a downward trend from a peak in the late 1990s, when it reached 12 percent of the labor force.

Long time series on aggregate unemployment rates in Italy are not readily available, since official statistics feature various definitional changes. In Figure 1 we report two long time series reconstructed on a self-consistent basis (and kindly made available) by Paola Casavola for the 1954-1998 period. The 'narrow' series is based on more stringent tests for willingness to work, and is closer to the current definition. The 'broad definition' series of higher unemployment rates gives more weight to administrative indicators, such as registration at employment offices, and is closer to official indicators reported early in the period. Neither of the series can be updated easily after 1998, but both offer useful historical perspective: despite the recent decline, the current unemployment rate is rather high from a long-run viewpoint. Throughout the 1954-98 period where comparably defined data are available, that unemployment rate averaged 6.8 percent. It was much lower in the $1960 \mathrm{~s}$, and one has to go back to the troubled post-war period to find unemployment rates (not reported) as high as those observed in the 1980 s and 1990s. A marked increase in unemployment took place from the mid 1970s, when unemployment was still only 5 percent, up to the late 1990s, when it peaked at 12 percent of the labor force.

Quantitatively, the rise in aggregate unemployment results from two separate episodes. The first episode starts in 1975 and lasts up to 1988, a period of 13 years over which the unemployment rate increased continuously, from about 4 percent in 1975 up to some 11 percent in 1989. After a small respite in 1989-92, which induced a cumulative fall in the unemployment rate by some two percent points, the unemployment rate increased again over the 1990s. In this second episode, the unemployment surge to 12.3 percent in 1998 was remarkably fast, particularly in 1993-95, when the unemployment rate increased in three years by more than 3 percentage points.

Unemployment rate data are available on a consistent basis (apart from a minor definitional change in 1991, which seems to affect mainly the labor force participation statistics) between 1977 and 2001, 
and are plotted in Figure 2. This relatively long period of 25 years includes the two unemployment surges, which are clearly marked in Figure 2. In section 4 we will examine how these large and persistent increases in unemployment can be attributed to an interaction of national and international shocks coupled with country specific institutions. In Figure 2, we see not only a persistent increase in unemployment (with two faster upward surges), but also a more recent and quite remarkable unemployment decline, by 2.5 percentage points between 1998 to 2001. The nature of such recovery deserves a careful analysis, since it may be partly linked to the slow institutional reform process that started in the second half of the 1990s. In Section 5 below we review that reform process and discuss the nature of the unemployment recovery.

\subsection{The current structure of unemployment}

Underneath the broad time-series picture of Figures 1 and 2, Italy features a complex structure of disaggregated unemployment rates. Focusing on disaggregated dimensions of the unemployment problem offers important insights into the interaction of market and institutional features in shaping the structure and dynamics of Italian unemployment. Table 1 provides simple statistics on the unemployment rate in July 2002, and shows that the Italian unemployment is characterized by three key dimensions of heterogeneity: a regional differential, an age differential and a gender differential. The unemployment rate in the North is as low as 4 percent, and essentially consistent with full employment (aside from a natural or frictional component) in that macro region. But the unemployment rate in the South is as high as 18 percent of the labor force. Indeed, more than 60 percent of the 2 million unemployed workers estimated by the labor force surveys live in the Southern regions. In the regions in the Center-North portion of Italy, the unemployment rate is lower than the national average, but still much larger than that of Northern regions. Such numbers suggest that a clear picture of Italy can only be provided by careful regional analysis. To the extent that high national unemployment is a reflection of highly concentrated unemployment, aggregate statistics should always be read from a regional perspective, and any solution to the Italian unemployment problem must come from a solution to Southern Italy's larger problem.

In addition to the regional dimension, Table 1 shows also that the Italian unemployment statistics feature an impressive age differential. Indeed, 40 percent of the unemployed workers appear to be young workers, which in Table 1 are classified as labor market entrants (never employed). The youth unemployment rate is as high as 26 percent at the national level, and reaches 30 percent among female youths. Finally, Table 1 shows that the Italian unemployment rate has an important gender dimension, which appears to be relevant more in terms of unemployment rates than in terms of actual unemployed workers. While the female unemployment rate is close to 12 percent of the labor force, the male unemployment rate is "just" 6.7 percent.

Despite a sizeable gender differential, however, Table 1 shows that more than 53 percent of the unemployment workers are male. This asymmetry is accounted for by the low female participation rate, which reaches only 33 percent of the working age population in the high unemployment regions of the South (Table 2). Obviously, the three dimensions outlined in Table 1 are largely interrelated, notably in the age and regional dimensions, as illustrated by the remarkable youth unemployment rate in the South, which reaches 50 percent of the labor force.

Perhaps surprisingly, the structure of unemployment in Italy is only very mildly related to skill differentials as measured by formal education. This is shown in Table 3, where we report the 2001 unemployment rates by region, age, and educational attainment. Table 3 distinguishes between 5 educational levels, which correspond to primary education ( 5 years of education), secondary education ( 8 years of education), professional and general high school diploma (13 years of education) and university degree. Totally unskilled workers are more likely to be unemployed, but higher education does not 
reduce the unemployment rates of young workers by much. In fact, it may even slightly increase them, as is the case in the North-East and North-West regions. And in the South, the youth unemployment rate is larger for individuals with a university degree than in the aggregate of the age class (respectively 28 and 26.8 percent). Only if we look at the unemployment rate by educational attainment for older workers the standard relationship emerges, and more educated individuals are mildly less likely to be unemployed. In summary, to be protected from unemployment in Italy it is much more important to be old than to be well educated. Overall, after controlling for age, education differentials do not appear to be structurally related to the Italian unemployment problem. ${ }^{1}$

\subsection{Regional and age differentials over time: 1977-2001}

Figure 3 plots the male regional unemployment rate from 1977 to 2001, and shows a marked increased of the national rate from 4.1 percent in 1977 up to 9 percent in 1998. This substantial increase is mainly a regional phenomenon. Indeed, male unemployment in the North hardly increases over time, as illustrated by the simple regressions of unemployment rates on a time trend reported in Table 4. Conversely, as we move to Southern macro regions, the male unemployment rate not only is larger in magnitude, but also significantly trended. Indeed, the trend coefficient on male unemployment in the South is as large as 0.47, and the level of unemployment ranges from 6.4 percent in 1977 up to 17.4 in 1999. Quantitatively, the North-South male unemployment differential rose from 3.3 percentage points in 1977 to almost 14 points in 1998, and is still 12 percentage points in 2001. To summarize, the increase in male unemployment rates is not an Italian phenomenon, but mainly a Southern Italy phenomenon.

Interestingly, Table 4 and Figure 4 show that Italian female unemployment is not significantly trended, despite a dramatic upward trend in female unemployment in the South. Over the twenty five years of our analysis, the North-South unemployment differentials rose from 10 percentage points in the late 1970s, up to a remarkable 22 percent in the late 1990s. But since the female labor force participation in the South is rather small, that upward trend does not translate into a clear trend in the aggregate female unemployment statistics.

Looking at the age dimension in Table 5, the unemployment rate is significantly upward trended for both the youth and the prime age groups. Indeed, a regression of youth unemployment on a constant and a time trend shows a value of the trend regressor of the order of 0.3 for both male youth unemployment (age 15-24) and male prime age unemployment (25-39). This suggests that the unemployment differential between youth and prime age workers has not increased over time. This seems to be the case for both male and female workers: the youth/prime-age male unemployment differential increased from 20 to 26 percent up to the late 1980s, but it then returned to a value of 20 percent in the late 1990s. For female workers, there seems to be actually a slight decrease in the age differential. Together with the previous observation and the large participation differential between prime age and youth workers (Table 2), most of the historical increase in unemployment was concentrated the 25-39 age bracket used to define "prime age workers" in Figures 3 and 4 and Table 5.

\footnotetext{
${ }^{1}$ More generally, education does not appear to have important labor market implications in Italy: perhaps as a reflection of higher-education institutional quality, the return to higher education is estimated by the OECD to be lowest in Italy among all countries considered in the Education at a glance studies. The microeconometric analysis of Boero et al (2002) finds that university performance has little or no impact on employment and earnings in Italy.
} 
This appears rather puzzling, since Bertola, Blau, Kahn (2002) and other cross-country studies establish that structural unemployment tends to be concentrated in secondary portions of the labor force. To investigate this further, we use the national-source data collected for Italy by Bertola, Blau, Kahn (2002), which provide a finer age decomposition than the one provided in Table 4. Specifically, these data (while not strictly comparable to those in the other Figures and Tables above) distinguish individuals aged 25-29 from individuals aged 30-39. These two age groups turn out to have very different unemployment dynamics. Figure 5 plots the shares of unemployment over time for five age groups. Three features of this graph are important. First, there is a substantial reallocation of the unemployment pool toward the age group 25-29, whose share among the unemployed rises from 12 to 25 percent. Second, there is a decline in the shares of unemployment accounted for the very young workers. Third, prime age individuals (30-39) do experience an increase in the share of unemployment, but such increase is just from 6 to 12 percent of the total. Thus, the share of individuals aged 25-29 increased much more than that of individuals aged above 30. This is further documented in Table 6, where we report the contribution to overall unemployment by different age groups. Table 6 shows that 65 percent of the absolute increase in unemployment is accounted for by the increase in unemployment of individuals aged 20 to 29. In other words, most of the increase in unemployment between 1978 and 1998 took place among individuals aged 20 to 29, and not among individuals aged 30 to 50 . Thus, when a broader definition of youth unemployment is allowed for, our analysis confirms that youth workers rather than prime age workers have been mostly hit by the increase in unemployment that took place over the last 25 years. Consistently with the theoretical perspective of Bertola, Blau, Kahn (2002), the contribution to aggregate unemployment of very young (14-19) and mature (40-65+) individuals declined quite sharply over the 1980s and 1990s. In Italy, as in other OECD countries, these individuals if not working are likely to be out of the labor force (in education or retirement) rather than unemployed. The share of mature unemployed individuals was further restrained by Italy's stringent employment protection legislation (discussed below), that largely prevented job loss until recently. The share of unemployed workers over 40 years of age, however, has increased from 10 to 15 percent over the 199097 period, and it will be interesting to return to this below when discussing recent institutional developments.

\subsection{Labor market flows}

Flow data are scarce in Italy. However, Bertola and Ichino's (1995) analysis of entry and exit rates in manufacturing firms with over 100 employees indicate that the Italian labor market was far from turbulent in the 1970s, when monthly exit and entry rates hovered around $0.8 \%$. Not surprisingly (in light of stringent employment protection legislation) few workers were dismissed, and few were hired, to imply that the brunt of unemployment fell on young labor market entrants. The 1975 and 1977 recessions both featured parallel drops of entry and exit rates: the (very limited) employment losses of large firms resulted from hiring freezes and minimal quits, with extensive labor hoarding. Data from the 1980s and, especially, from the 1990s offer an increasingly different picture. Entry and exit rates now diverge from each other during recessions, so that employment losses are due to higher (involuntary) exit rates rather than to hiring freezes, consistently with institutional evidence of increasing flexibility starting from the mid-1980s. The recession of 1993-94 stands out for an unprecedented amount of job destruction: monthly exit rates reach a maximum of about 12 per thousand at the end of 1992. Exit rates decrease as the Lira is devalued and the recession comes to an end: interestingly, however, exit rates remain extraordinarily high in historical perspective. All this confirms that the Italian labor market became more flexible in the 1990s, a fact that we will bring to bear on recent experience in Section 5 below. 


\subsection{Shadow economy}

As mentioned when discussing Figure 1 (see also Jones and Riddell, 1999), the definition of unemployment is unavoidably less than clear-cut. In Italy, as we discuss below, several types of temporary layoff, non-market employment, and 'activation' programs make up a gray area of individuals who are not really employed but (as is the case for ALMP participants in other countries) are not counted as unemployed.

Further, official employment statistics (though not, at least in principle, the survey-based ones) may be imprecise due to undeclared or 'black' employment pools. The shadow economy is important in Italy and, like in other European countries, its size trends up in time: different estimates suggest that shadow activity increased by some 10-15 percent of GDP in the 70s to some 30-40 percent in the 1990s. This upward trend parallels that of Italy's aggregate unemployment rates. Not surprisingly, and quite interestingly from the institutional perspective we lay out below, the incidence of the shadow economy varies importantly within Italy, again quite like unemployment. Regions with low productivity and high unemployment display significantly larger shares of unregistered activities and employment than the country averages. Boeri and Garibaldi (2002) offer a detailed account and analysis of this phenomenon. Figure 6, reproduced from that paper, plots the average shadow employment rate over 20 Italian regions, and shows that shadow employment varies between 10 percent in Piedmont (North-West) and more than 30 percent in Sicily (South). These estimates suggest that the proportion of irregular employment may be as high as 30-35 per cent in the South, around 20 per cent in the Centre and at one-digit level in the North-West and the North-East, the latter macro-region being the one with the lowest level of shadow activity. A portion of this variability may be accounted for by the various regions' heterogeneous production structure. However, it is large within industrial branches marked not only in agriculture, but also within industry, with the South displaying an incidence of shadow employment that is twice as high than in the rest of the country. There is no tendency over time to the narrowing of the regional differentials in the incidence of the shadow economy: in 1995 the South to Centre-North gap was roughly the same as 10 years earlier.

\section{Institutions}

We begin by interpreting high and persistent unemployment in light of labor market regulation, which we review in the first subsection for the case of Italy. Of course, we recognize at the outset that regulation is not meant to increase unemployment. Rather, unemployment is an important side effect of rules meant to improve the welfare of workers, and a not unintentional side effect of higher wages from the perspective of unions, whose role in Italy is reviewed in the second subsection.

\subsection{The character and history of Italian labor market regulation}

Bertola and Ichino (1995) offer an extensive review of Italian labor market institutions and reforms up to the early 1990s. Briefly, the 1970 Charter of Workers' Rights (Statuto dei Lavoratori) introduced very stringent regulation of employment relationships, including hiring and firing procedures, the compensation structure, rules for workers mobility and promotions within firms, and safety of working environment. "Rigidity" of the Italian labor market was furthered by subsequent legislation, including a 1974 reform of labor litigation that made it easy for workers to sue employers for non-compliance with the Charter. The character and evolution of Italian employment protection legislation is reviewed in detail by Bertola and Ichino (1995). In essence, dismissal is possible (for employers subject to the Charter, and workers on regular employment contracts) only if appropriately motivated. Article 18 of the Charter prescribes that employers if found guilty have to compensate dismissed workers in kind, 
restoring their employment status and paying back wages for all the period of litigation plus other monetary penalties.

Wage contracts were also strongly centralized around 1970, when previous provisions for regionally differentiated wages were abolished and an industry-specific negotiated wage structure was mandatorily extended to all workers and all employers. Further, the wage indexation system introduced in 1975 stipulated the same cost-of-living allowance for all workers, regardless of pay. Hence, low-wage workers were more than fully compensated for inflation, and wages were strongly compressed, especially at the low end of the distribution. As shown in Figure 7, wage differentials decreased strongly (as measured by the difference between the median and the $10^{\text {th }}$ percentile of the earnings distribution) through the early 1980s (the indexation system was reformed in 1983). In the absence of centralization and wage-compressing indexation, wage differentials would of course have differed across regional and demographic dimensions. To the extent that they were not allowed to do so, it is unsurprising to see (in the previous section's figures and tables) a wide divergence in various regions' and demographic groups' unemployment rates.

To the extent that wage rigidity and strong dismissal restrictions were problematic for the employers' profitability, throughout the 1970s and the early 1980s various policy instruments were introduced to allow employers to dismiss redundant employees without depriving them of wages and (at least nominal) employment status. Box 1 outlines the definition and character of these programs, which in Italy played a role broadly similar to that of other countries' Unemployment Insurance systems, relieving downward pressure on wages as well as sustaining the purchasing power of job losers. The Italian income support system is peculiar in various respects, however. First, workers need to be previously employed by relatively large firms in order to be entitled to these non-employment subsidies; second, those drawing such benefits would not be counted among the unemployed, since (as they are supposed to be reinstated in their previous job) they are not supposed to exert much search effort. In the 1970s and 1980s, these systems involved a substantial pool of quasi-unemployed individuals: use of the CIG and CIGS temporary-layoff schemes peaked at some 160 million hours in 1984, equivalent to some 80,000 full-time equivalent subsidized unemployed.

The institutional framework of "passive" CIG policies outlined in Box 1 is still in place, but since the early 1980s several flexibility-oriented features have been introduced. On the wage front, the indexation system was progressively reformed and eventually abolished in 1992. Employment protection remained quite stringent, and in 1990 was extended to small firms. However, it was somewhat weakened by labor courts' less restrictive interpretation of justifiable dismissals and, especially, by the collective redundancy procedures introduced in 1991 along with restrictions on entitlement to "temporary" income support schemes, both the pre-existing CIG and the new "special" unemployment subsidies (see Box 1)., A 1993 law partially backtracked on that reform, however, to imply that the evolution towards greater flexibility was generally perceived to be quite hesitant, with adverse effects on employers' incentive to hire (see Bertola and Ichino, 1995, for a detailed analysis). To the extent that labor market regulation is at least partly endogenous to labor market conditions, such hesitancy is not surprising in light of the surge in unemployment experienced by Italy in the early 1990s and quite apparent in Figure 2 above.

The unsustainable character of the 1970-80s regime of subsidized "temporary" layoffs, however, also led to introduction of more "active" policy instruments, meant to foster employment of workers made redundant by declining sectors and of young long-term unemployed market entrants. We review the character of these instruments in Box 2: briefly, these are quite limited, and Italy's "active" labor market policies appear extremely underdeveloped from a comparative perspective. 
Regulation of hiring, however, also became less stringent, especially over the 1990s. While employment protection remained largely unreformed for regular employment relationships, a variety of non-standard contracts were exploited more widely, and possibilities for temporary employment were extended by several legislative provisions. Box 3 reviews these aspects, and we return to the implications of this institutional evolution for Italy's recent experience in Section 5.

\subsection{The role of unions}

In the post-war period three union confederations have played a major role in the Italian labor market, and until recently acted together in wage negotiations as well as in exerting pressure on legislative processes. Within each of the three Confederations different political orientations coexist, but CGIL was formerly Communist, UIL was formerly Christian Democrat, and UIL was "lay." In addition, a number of smaller unions are increasingly important (COBAS). The evolution over time of union membership and activity is nicely summarized by the two series reported in Figure 8. Union membership rose sharply in the late 1960s-early 1970s season of industrial unrest, peaked around 1980, and has been declining since (even more sharply than would appear from official figures, since up to $50 \%$ of the main union confederations' members are now retired). Strike activity was very intense in the 1970s, and subsided sharply in the 1980s and, especially, in the 1990s.

These data support a stylized interpretation of unions' role in shaping Italy's labor market performance. There is no doubt that union wage pushes (supported by mandatory extension of centrally bargained contracts, and by automatic indexation and wage compression) played an important role in fostering unemployment growth in the 1970s and early 1980s. Since the early 1990s, however, unions have played a very different role. The central bargaining framework was reformed so as to privilege inflation stabilization (a prerequisite for EMU membership). Box 4 reviews the main features of this system. Briefly, wages were set on the basis of "programmed" inflation rates, and employment-oriented fiscal instruments (as well as employers' commitments to investment and employment) were bargained together with wage platforms. As a result, the 1990s were a decade of wage moderation in Italy.

\section{History and shocks}

It is easy to interpret Italy's aggregate and disaggregate unemployment experience in terms of the interaction of institutional features with such shocks as the oil price hikes and productivity slowdown of the 1970s-80s, and the fiscal and monetary restrictions in the 1990s run-up to EMU. It is of course no coincidence that the two episodes of sharp and sustained unemployment increase were observed in 197588 and 1993-98. However, it is important to note that the character of shocks and of their interaction with institutions was quite different in the two episodes.

\subsection{Two episodes of increasing unemployment}

When Italy was hit by the oil shock and productivity slowdown in 1973, unemployment rose only modestly, because wages were high and rigid but employers were largely prevented from dismissing redundant employees. As mentioned above, both hiring and firing remained quite subdued initially. Young labor market entrants, of course, began to find it quite difficult to obtain employment, and the remarkable growth of unemployment over the following 15 years was largely concentrated on those among the young who did not exit the labor force to pursue education. And it is not surprising, in light of strong regional wage equalization, that the largest increase in unemployment should be observed in the less productive South, with a particularly pronounced divergence increase in 1985-89. 


\section{5-1988: Fiscal crowding out and the cost of disinflation}

To understand the character of the first episode, which we dated 1975-1988, two key macroeconomic developments seem particularly important, namely the dynamics of government spending and the disinflation process. Figure 9 reports the dynamics of public primary deficits and public employment (as a share of dependent employees): both grow sharply initially, and reverse towards stagnation or decline in the 1980s and (especially) 1990s. The theoretical framework and cross-country panel evidence of Algan, Cahuc, and Zylberberg (2002) are readily applicable to the interaction of these variables with Italy's labor market institutions and performance. In general, public employment can reduce unemployment at given wages, and both the growth of public employment and the aggregate demand stimulus of government deficits arguably contributed to limiting unemployment growth in the 1970s and 1980s. Wage rigidity, in the face of supply shocks, would potentially have resulted in much sharper unemployment increases in Italy. But public employment generally increases unemployment when it increases equilibrium wages (destroying private jobs and drawing additional workers in the labor force). This can explain, in particular, high unemployment rates by well-educated individuals in the South. Public jobs pay the same wage everywhere, and life is cheaper in the South where private jobs are scarce. Hence, unemployment should be (and was) concentrated in that region, where it took the form of waitunemployment by highly educated individuals.

Following the supply shocks of the 1970s, which resulted in a simultaneous increase in inflation and unemployment from the mid 1970s up to the early 1980s, throughout the 1980s Italy experienced a remarkable disinflation process, which brought CPI inflation from 21 percent in 1980, down to less than 5 percent in 1988 (Figure 10). Monetary policy became more independent in 1981, when the Bank of Italy stopped automatically financing budget deficit (the divorzio). In addition, the indexation system was reformed in 1983, and Italy was also forced to slowly open its capital market, as required by participation in the European Monetary System (EMS), which was introduced in 1978. These various developments obvious helped the disinflation process, but the tightening in monetary policy over the 1980s was accompanied by a significant sacrifice ratio, despite the very loose fiscal policy implemented in that period. Between 1980 and 1988, while the inflation rate fell by 17 percentage points, the unemployment rate rose from 7.6 to 12 percent, with a sacrifice ratio of 0.25 : each percentage point fall in inflation was accompanied by an increase in unemployment of some $1 / 4$ of a percentage point.

\section{2-1998: Fiscal retrenchment and the road to EMU}

Serious budgetary problems, however, lead public employment to flatten out. Privatization also arguably has employment consequences (in 1988, government-owned firms accounted for $84 \%$ of employees in the energy and extraction sector and for $64 \%$ of employees in transportation and communications: the partial or complete privatization of State firms in those sectors certainly put pressure on those jobs). Thus, far from buffering the short-run consequences of wage rigidity in the face of supply shocks, government spending and unemployment have in recent years exacerbated employment losses. Despite wage moderation and limited flexibility-oriented reforms, the recession of the early 1990s resulted in a sharp increase in unemployment. Overall, there is a significant negative correlation over time between the size of the primary budget deficit and the overall unemployment rate. (Figure 11). In the mid 1970s, the primary budget deficit was as large as 8 percent, and unemployment was still 8 percent. When unemployment reached its peak in 1998, Italy experienced a 6 percent primary surplus: a remarkable fiscal adjustment effort that, accompanied by some creative accounting, opened the gate to EMU membership.

While the time correlation between the budget deficit and unemployment is overall clear and significant, the time evolution highlighted in Figure 11 also illustrates the different nature of the two 
increasing-unemployment episodes. The points corresponding to the first episode are all positioned above the regression line, suggesting that the increase in unemployment was accompanied by loose fiscal policy. Conversely, the point corresponding to the second episode are all below the regression line, since the increase in unemployment took place at a time of substantial fiscal retrenchment. The second episode also features important regional developments. The divergent pattern of unemployment rates between Northern and Southern Italy, in fact, is particularly striking in the aftermath of the aggregate shocks that hit Italy in the early 1990s. In the more dynamic and competitive regions, the contractionary effects of fiscal retrenchment required by the Maastricht Treaty were offset by the 1992 devaluation and by Italy's subsequent excursion out of the European Monetary System. In the South, conversely, the unemployment rate rose from $16 \%$ to over $23 \%$ in the first half of the 1990 s, and employment and GDP both fell by over $10 \%$ as wages and productivity remained roughly unchanged.

To summarize, the divergent dynamics of unemployment in the 1970s and 1980s were largely explained by different reactions (in light of wage rigidity) to similar aggregate shocks, partly buffered by government policies. In the early 1990s, conversely, shocks were different in the North and in the South, and the still very limited flexibilization of labor market institutions (especially along regional lines) did little to prevent unemployment from diverging again.

\subsection{Regional productivity differentials}

As discussed in more detail by Bertola (2000), relative wage and productivity indicators for the manufacturing sectors of Southern and Northern Italy display a convergent productivity pattern until around 1970, when national contracts began to impose stringent lower bounds on each sector's wages throughout Italy. After some divergence, relative productivity remained lower in the South, and flat from 1975 to the present. In the manufacturing sector, take-home pay was only about $10 \%$ lower in the South than in the other regions, and not sufficient to induce outmigration in light of cost-of-living differentials and of fairly small job-finding rates in the North. Productivity differentials are twice as large, at about $20 \%$ : only a smaller fiscal wedge, largely reflecting social-security contribution exemptions, makes it possible for employers' unit labor costs to be roughly equalized throughout Italy (as must be the case, of course, if firms are free to choose where to produce). While employed Southerners earn almost as large a wage as their compatriots do, few are indeed employed, because their productivity remains lower. But few migrate (see, e.g., Brunello, Lupi, and Ordine, 1999) because centralized wage bargaining does not allow them to put pressure on wages in the North, where their standard of living would not be higher. Migration outflows from the South have been sharply higher in recent years, and this may be evidence of a permanently higher responsiveness to wage and unemployment rate differentials, as may be caused by reduced government expenditure overall and especially in the South.

\subsection{Taxation and the upward trend of the shadow economy}

Over the last twenty years, Italy experienced a remarkable increase in tax revenues: income tax, consumption taxes and payroll taxation as a share of GDP experienced a clear upward trend, which took place at the same time as the increase in the unemployment rate. In terms of labor market impact, the most important development is clearly that of payroll taxation (Figure 12), whose total revenue increased from 11 percent of GDP in the early 1970s up to more than 15 percent in the late 1990s. In the last few years, a substantial decline is observed, and may have contributed to the recent developments discussed in the concluding section below. 
Several authors, and Daveri and Tabellini (2000) in particular, have argued that the increase in payroll taxation is responsible for the increase in unemployment observed in European economies. The evidence may however suffer from spurious correlation over time and with other country-specific characteristics, however. And well-understood economic arguments suggest that payroll taxation should be independent of unemployment in the long-run (Pissarides, 1998): most of the burden of payroll taxation is shifted into labor and, as long as a workers' outside opportunities are taxed at the same rate as the wages, unemployment is invariant to the size of the payroll tax. In addition, microeconometric studies applied to the Italian case suggest that the intensive margin of labor supply is largely inelastic (Aaberge et al., 1999).

While the rise in payroll taxation is arguably not responsible for the increase in unemployment, it can still have important effects on two dimensions of the labor market: the extensive margin of labor supply and the size of the shadow economy. Indeed, models in which the size of the labor force is endogenous, alongside the employment and the unemployment rate, show that increase in payroll taxation, even if neutral on the unemployment rate, may have important decision on the participation decision (Garibaldi and Wasmer, 2001). Empirically, the fall in the Italian employment rate is sensibly correlated with the rise in payroll taxes, even though cross-country panel regressions find that this link is not empirically robust to inclusion of country and time effects (Bertola et al., 2002).

Like that of unemployment, the upward trend in the shadow economy can also be explained by simple theoretical and institutional mechanisms. The heavy and increasing over time tax, social security and administrative burdens imposed on activities which are officially registered tends not only to decrease official and overall employment, but also to increase the latter's shadow component. Stringent labor market regulations can have similarly obvious effects if they increase the cost of official employment relative to that of irregular employment. Boeri and Garibaldi (2002) show that average unemployment rate and the average shadow employment are very strongly positively correlated across 19 Italian regions on an average 1995-99 average basis. They also document a positive time-series correlation between the share of "irregular" jobs in total employment (as estimated by Istat) and the unemployment rate, in the Centre-North and in the South of Italy for all years in which both series are available. That is consistent with a positive relationship between unemployment and the shadow rate both cross-sectionally (shadow employment is higher in the high-unemployment Southern regions) and over time. In the years where unemployment is on the rise, the shadow rate is also increasing. This may rationalize why Governments allow for variable enforcement of the rule of law depending on the amount of labor slack: the larger the slack, the looser law enforcement.

\section{Recent developments and policy tensions}

In this paper we have argued that interpreting Italy's unemployment experience in light of standard theoretical approaches is not difficult, and quite insightful. Our necessarily brief review of time-series and cross-sectional aspects finds that both can be explained readily by the interaction of institutions and shocks. Of course, inference cannot be univocal when analyzing an individual country's history, because very little can be kept fixed when both evolving institutions and more or less dramatic macroeconomic developments are allowed to play a role. Hence, it would be in principle possible to interpret the same data in terms of other theoretical frameworks. Viewing Italy as a particular set of observations within a coherent data set of industrialized countries, however, offers statistical support to our perspective, and 
can discipline our effort to offer a more detailed assessments of disaggregated and time-series relationships between macroeconomic dynamics and labor market institutions.

Fig: 11 Primary Budget Deficit and Total Unemployment: 1977-2001

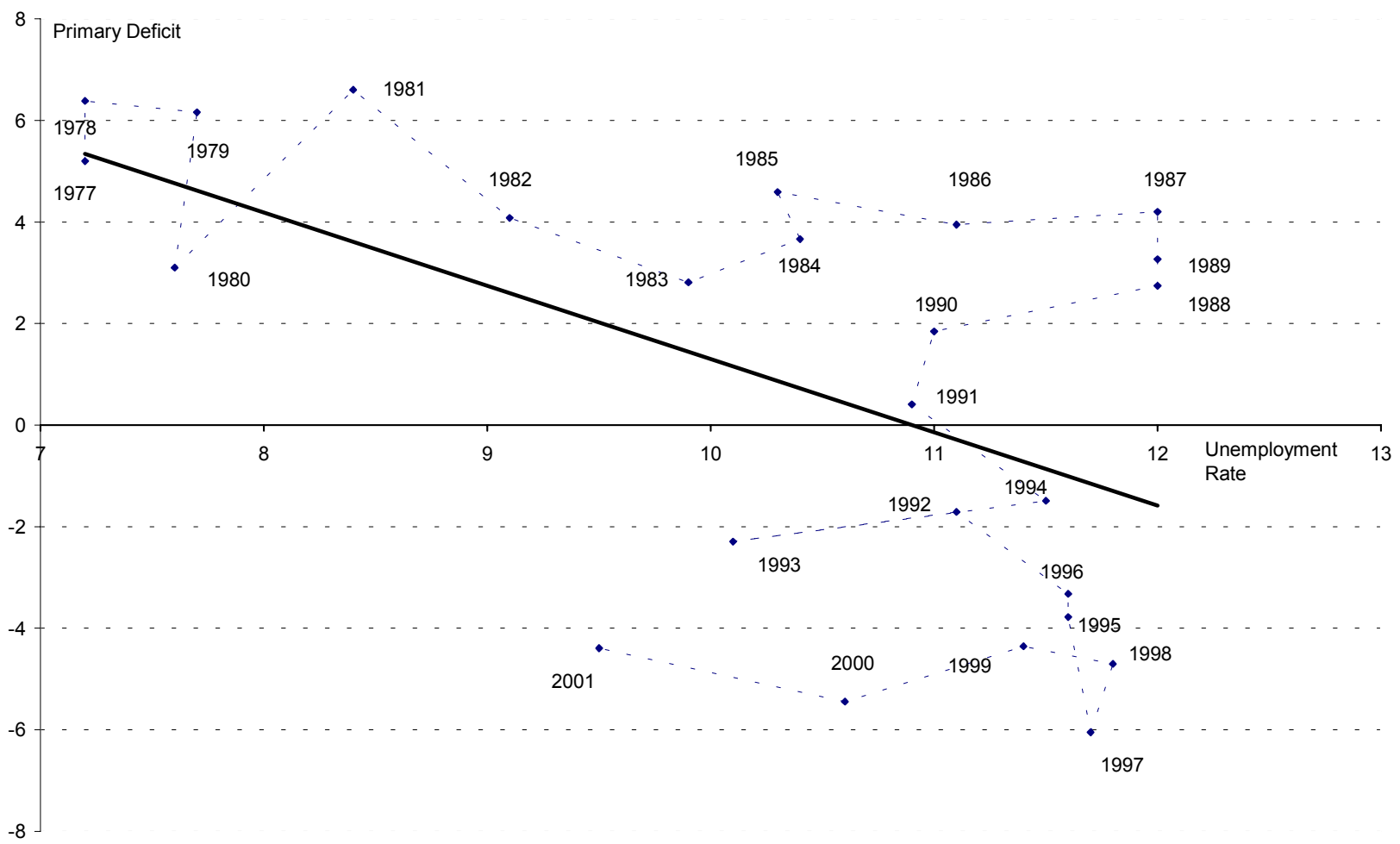




\section{Source: OECD and Bank of Italy}

In the second half of the 1990s, employment rates have increased rather sharply. The South has benefited marginally more than the North from the cyclical upswing, and labor productivity growth has declined. In 2002, Italian GDP is growing very slowly, perhaps at a $0.6 \%$ rate for the year. Yet employment is growing at some $1.2 \%$ annual rate, and the unemployment rate at $9 \%$ is the lowest in 10 years. As repeatedly mentioned, the Italian labor market problems are mainly to be found in the South, and even across regions recent positive experiences mirrors previous negative developments: in the South, employment is growing at $2 \%$ per year, much faster than the national average. And even the previous trend away from regular employment is not confirmed in recent experience, as the share of term contracts is stable at $10.4 \%$ of dependent employment and many of the newly created jobs are standard, protected ones. For Italy, growth used to be jobless. Now, if anything, growth-less hiring is observed, and slow productivity growth may replace non-employment as a cause of policy concern. Why should such this be the case now and, indeed, since the mid-1990s? There are at least three possible (and interrelated) reasons for this apparent regime change.

First of all, the Italian labor market has become more flexible since the mid-1990s: the 1997 "pacchetto Treu" law, the 2000 "Salvi" law relaxing regulation of part-time employment, and the 2001 deregulation of term contracts all made it possible to create 'atypical' jobs (see Box 3). Moreover, the quasi-dependent (but formally self-employed) "Collaborazione coordinata e continuativa" employment relationships have grown very substantially throughout the 1990s. All these flexible employment relationships played a very important role in the 1997-2000 boom years, when GDP was growing at over $2 \%$ per year. Flexibility, however, cannot explain the resilience of employment creation in the 2001-02 slowdown: if anything, in fact, a more flexible labor market should destroy more jobs during a downturn. Second, and also very importantly, wage moderation has prevailed in Italy since the early 1990s. The pre-set planned inflation rate was ex post lower than actual inflation throughout Italy's disinflation, so that real wages did not keep up with productivity (and employment grew, along the labor demand curve). The slowdown that followed the late-1990s boom was accompanied by continued (if less pronounced) wage moderation.

However, a third important mechanism is at work, and explains an important feature of recent experience: the strong growth of regular, open-ended, protected employment relationships, especially in the South, and probably at the expense of continued growth in temporary employment. This phenomenon is probably a reflection of hiring subsidies, in the form of tax credits, that were introduced in the second half of the 1990s. Workers over 25 years of age, not employed on a regular contract in the previous 2 years, would entitle the employer hiring them to a tax credit amounting to euro 413 per month (euro 620 in the South). The scheme was temporary, for a 3-year period originally scheduled to end in December 2003 (the current Government repealed this tax credit, and may or may not reinstate it). Since the fiscal burden was substantially reduced by the scheme, it may be the case that part of observed employment growth is just due to legalization of previously 'black' employment relationships. Evidence is lacking, however, and employers have largely ignored an even more generous fiscal treatment (provided by a parallel 'amnesty' program) of employment relationships resulting from ones that were previously existing, but undeclared.

In summary, recent institutional changes are sensibly linked to recent labor market developments. In the last 6 years, Italy has been able to generate many jobs, despite still rather restrictive fiscal policy (see Figure 11, where unemployment declines horizontally), and despite a sharp cyclical slowdown. This is welcome, since its employment rate (even after its strong recent increases) stands at only $55.8 \%$ of 
working-age population, far below the EU target of $70 \%$ by 2010 . Of course, productivity growth (sustaining wage growth) is needed to make high employment appealing, and this has been lacking in recent years. It remains to be hoped that appropriate reforms (not only in the labor market, but also in product and financial markets) will be able to deliver positive developments in coming years. The lessons of the past 40 years are quite relevant to current policy debates, but European economic and monetary integration poses new challenges to Italy's labor market. In Italy, the reform tension can be largely summarized in terms of a need to restructure labor market interactions to address the microeconomic efficiency and distribution issues arising as Italy is a fraction of an integrated Eurozone, rather than the macroeconomic stability issues that were preeminent in previous years. Before EMU, the unemployment problem was addressed by macro policies, largely based on wage indexation and bargaining coordination schemes. These are clearly less relevant in the new millennium, when Italy needs to foster microeconomic flexibility in order to compete with other economic and social systems. The relevant reform process has just begun, and the lessons of historical experience will remain relevant for many years to come. 


\section{REFERENCES}

Algan, Yann, Pierre Cahuc, and André Zylberberg. 2002. "Public Employment and Labour Market Performance.” Economic Policy 34, pp.9-65.

Aaberge, Rolf, Ugo Colombino and Steniar Strom (1998) "Labour Supply in Italy: An Empirical Analysis of Joint Household Decisions With Taxes And Quantity Constraints" Journal of Applied Econometrics 14: 403-422

Bertola, Giuseppe (1999) "Microeconomic Perspectives on Aggregate Labor Markets," in O.Ashenfelter and D.Card (eds.), Handbook of Labor Economics vol.3B, Amsterdam: North-Holland, 1999, pp.2985-3028.

Bertola, Giuseppe (2000) "Labor Markets in the European Union," ifo Studien 1/2000, pp.99-122.

Bertola, Giuseppe, Francine D. Blau and Lawrence M. Kahn (2002) “Labor Market Institutions and Demographic Employment Patterns,” CEPR DP3448, NBER w9043.

Bertola, Giuseppe, and Andrea Ichino (1995) "Crossing the River: A comparative perspective on Italian employment dynamics", Economic Policy 21, pp.359-420

Blanchard, Olivier J., and Justin Wolfers. 2000. "The Role of Shocks and Institutions in the Rise of European Unemployment: The Aggregate Evidence.” The Economic Journal 110(462): C1-33.

Boeri, Tito, and Pietro Garibaldi (2002) "Shadow Activity and Unemployment in a Depressed Labor Market”, CEPR Discussion Paper 3433.

Boero, G., A.McKnight, R.Naylor, and J.Smith (2002) "Graduates and Graduate Labour Markets in the UK and Italy," Lavoro e Relazioni Industriali 2/2001, pp.87-124.

Brunello, Giorgio, Claudio Lupi, and Patrizia Ordine (1999), "Widening Differences in Italian Regional Unemployment," Università di Padova and ISAE (Rome), working paper.

Checchi, Daniele, and Claudio Lucifora (2002) "Unions and Labor Market Institutions in Europe," Economic Policy

Daveri, Francesco and Guido Tabellini, (2000), "Unemployment, Growth and Taxation in Industrial Countries", Economic Policy, 30, 49-104

Garibaldi, Pietro, and Paolo Mauro (2002) “Anatomy of Employment Growth,” Economic Policy 34, pp.67-114

Garibaldi, Pietro and Etienne Wasmer (2001) "Labor Market Flows and Equilibrium Search Unemployment," IZA Discussion Paper 406.

Jones, S., and W.J.Riddell (1999), The measurement of unemployment: an empirical approach, Econometrica 67:1

Pissarides, Christopher A. (1998), "The Impact of Employment Tax Cut on Unemployment and Wages: The Role of Unemployment Benefits and Tax Strcuture”. European Economic Review, 42(1), 155183. 


\section{BOX 1: "Passive" labor market policies}

Conventional unemployment insurance is not an important labor market institution in Italy. Rather, the country features a large assortment of subsidies for job losers and some subsidies are also paid to labor market entrants (who, while unemployed, can also rely on income provided by strong family relations). Overall, the Government pays about 600 million euro.

Indennità di disoccupazione ordinaria offers short-duration and rather low benefits to dismissed workers. The benefit used to be trivially small, but it has been increased starting in 1997 (first to a $20 \%$, then to a $30 \%$, and since 2001 to a $40 \%$ replacement rate), and is currently paid for 6 months only ( 9 months for workers over 50 years of age). The Government plans to increase the replacement rate to $60 \%$ in the first 6 months, and to extend the duration of the previous $40 \%$ subsidy for a further 6 months. The scheme is funded by a payroll tax, and its low generosity implies a surplus (about 130 million euro in 2001).

Agricultural workers can draw a special subsidy of about $30 \%$ of previous wages, if they have been working for at least 78 days in the previous year (the benefit duration is in all cases limited to the period worked in the previous year). This scheme generates a large deficit (about 1.5 billion euro in 2001).

Special schemes also exist for industrial workers. Cassa Integrazione Guadagni Ordinaria (CIG) pays $80 \%$ of previous wages (up to a ceiling) provided the layoff is temporary (maximum duration 3 months). The scheme is in surplus (1.7 billion euro in 2001). Workers with at least 3 month seniority laid off by industrial firms with over 15 employees (or retail and certain service firms with over 50 employees) can draw Cassa d'Integrazione Guadagni Straordinaria (CIGS) benefits, provided the firm is bankrupt or needs to restructure its activity: over the last two years, earnings, sales, and debt must have evolved badly and there must have been no new hirings (or at most replacement hirings); a detailed restructuring plan must be prepared and approved by the Government, including disaggregated information about redundant workers.. The CIGS replacement rate is also $80 \%$, but its duration is longer (up to 36 months in a 5-year period).

Licenziamenti collettivi (collective redundancy) procedures were introduced in 1991 to deal with plant closures and partial failures of restructuring plans. The employer, the unions, and the government consult for 75 days to find ways to avoid redundancies or reallocate redundant labor to other activities outside the firm. Workers are then entitled to trattamento di disoccupazione speciale (CIS), or trattamento di mobilità. Workers previously drawing CIGS, if not reinstated due to failure of the restructuring plan, are also entitled to this subsidy, amounting to $80 \%$ (like CIGS) for the first 12 months and to $80 \%$ of that afterwards (the duration of this benefit varies from 1 to 3 years across age groups and regions, ranging up to 36 months for workers over 50, and to 48 months for workers over 50 in the South). This scheme generates a deficit of about 850 million euro per year. Finally, mobilità lunga (originally introduced in 1991) allows older workers in 'crisis' situations to draw benefits until pension age. Until 2002 such benefits could be granted on the basis of ad hoc decrees regarding specific troubled firms. From 2003 the scheme is abolished, but may be reinstated (as it was in previous occasions) by new laws with funding provisions. 


\section{BOX 2: "Active" labor market policies}

These are very weak in Italy, a country that is only beginning to develop the tracking, training, and placement facilities envisioned under this heading. Traditionally, employment offices were simply maintaining lists of registered unemployed for privileged hiring by large firms and the public sector, and offered no placement services. The only sense in which a "pathway to work" can be identified in the current Italian institutional environment is that a variety of special employment contracts and training opportunities are only available for long-term unemployed individuals (youth and regional characteristics are also important for access to such instruments). Like the passive instruments reviewed in Box 1, these tend to be targeted to previously employed individuals and (more recently and less generously) to youth long-term unemployed.

The most important policy instrument aimed at fostering youth employment is a training contract program ("Contratti di Formazione e Lavoro") allowing term employment of young workers at considerably lower payroll taxes. More than 1,800,000 workers below 29 years of age found at least a temporary job under this program between 1985 (when 180,000 such contracts were signed) and 1990 (when the number of new contracts had grown to 530,000). The eligibility and contribution rules of this program vary considerably across regions and over time. Their training content is very limited: the Formazione e lavoro contracts can be fairly characterized as "low quality--low wage" new jobs, with lower pay, smaller benefits, and especially far less job security than regular contracts.

Various schemes provide income support to youth unemployed: Lavori Socialmente Utili (LSU) and Lavori di Pubblica Utilità (LPU) are public sector make-work schemes, initially targeted to workers made redundant by medium-large firms who had exhausted their CIGS and mobilità entitlements, then extended to young long-term unemployed individuals. Currently, $56 \%$ of the workers engaged in such public schemes were originally made redundant (and are typically low-educated primary breadwinners in their $40 \mathrm{~s}$ ), but $44 \%$ have never been otherwise employed: these are typically young, educated beyond compulsory schooling, and equally likely to be male or female. These schemes are funded directly by the central Government, and cost about 250 million euro in 2001.

Contratti di reinserimento are available to the unemployed for over 12 / 24 / 36 months receiving special unemployment benefits: reduction of contributions by up to $75 \%$ and up to 3 years, depending on length of unemployment period. Long-term registered unemployment status (and young age) is typically required for access to some training opportunities financed by EU Social Fund and administered by Regional governments.

Being registered in Liste di mobilita' (formerly employed individuals, who lost their jobs after collective layoff or plant closure) entitles workers to obtain a job under the same contribution rules as apprenticeships: small lump-sum contributions (10 euro/month) for a period that varies across sectors according to national employment contracts, at least 18 months and up to 4 years. Similar provisions apply to those in "Cassa Integrazione Straordinaria" (if not rehired, these individuals enter "Liste di Mobilita" when entitlement runs out).

Those unemployed for more than 24 months have access to contracts at half the regular contribution rate for 36 months (additional reductions in the South and very small firms). 


\section{BOX 3: Temporary and non-standard contracts}

The Italian institutional setting, as shaped in the 1970 Labor code, is framed around the protection of the open ended employment contract, which is view as the "standard" and default labor contract. Along this dimension, already in 1962 an Italian law put stringent regulation on temporary employment relationships limiting them to seasonal or unusual activities (or top management), and restricting their renewal (under penalty of conversion to a standard open-ended employment contract). In 1977 a law allowed temporary employment for retail and tourism industries, and in 1983 all sectors were allowed to hire on a temporary basis in case of activity acceleration. In 1984 "Contratti di Formazione e Lavoro" were made possible for youth (16-32 years of age), and not only had a fixed (1.5 to 48 months, depending on age and qualifications) duration but also entailed a payroll tax cut. These contracts were meant to have some training content and provide a stepping stone to permanent employment, but in practice made temporary hires much easier for employers. More recently, in 2001 Italy implemented the 1999 EU Directive on temporary work. For the first time, the law made it possible to hire workers on a temporary basis (provided the reasons for term employment are clearly stated in the contract), and no longer treated open-ended employment as the default relationship with special exceptions. As a result of this medium term process, the share of temporary contract grew by some 4 percent of the employment base in the early 1980 s, to some 10 percent in 2000.

The legislation on part-time work followed a similar process. The part-time was formally introduced in 1984, but it was seen as an exceptional regime, and was de-facto overly taxed by the requirements of considering payroll taxes on health insurance on the basis of working days rather than the number of hours worked. Such disincentive was removed in 1996. In 2000, Italy implemented the 1997 Directive on part-time work. Overall, part-time work is now much more flexible, and employers have the right to switch full-time workers to part-time, as long as workers accept the change.

Alongside increased flexibility towards temporary and part-time contracts, other legislative initiatives allowed various "atypical contracts" to be put in place, and made the Italian labor market flexible "at the margin", with a reform process similar to that observed in many high unemployment countries, including Spain and France.

In 1997, a series of legislative initiative named after the Labor Minister ("Pacchetto Treu") introduced interim workers in the Italian institutional setting. The instrument, initially aimed at offering flexible labor supply in the aftermath of temporary shocks, turned out to be particular popular among Italian entrepreneur, which exploited it not only as a short run buffer, but also as a gateway toward more permanent employment. Today, interim workers account to some 0.5 percent of the dependent employment, and the number of paid days received by interim workers grew from 200 thousand in 1998 to more than 2 million in 2001.

Finally, Italy features another sizeable form of employment contract, which is legally framed as a self-employment, but very often has the attribute of dependent employment. Indeed, "CO.CO.CO." (Collaborazione Coordinata e Continuativa) workers include a variety of professional figures, from qualified professionals to de-facto dependent workers. Up to 1997 these workers were not even obliged to pay social security contributions, and at the time of writing they are still not eligible for maternity leaves, unemployment insurance and paid vacation. There are no official statistics on the number of CO.CO.CO, but administrative sources estimated more than 2 million contracts in 2000 . 


\section{Box 4: Wage setting coordination framework}

Employment pacts have been an essential component of Italy's policy environment in the 1990s. Protocollo sulla politica dei redditi e dell'occupazione, sugli assetti contrattuali, sulle politiche del lavoro e sul sostegno al sistema produttivo (Protocol on incomes and employment policy, on contractual arrangements, on labor policies and productive system support) of July 1993, and Patto del lavoro (Work Pact) of September 1996 were important milestones in Italy's path towards EMU. Both were explicitly oriented to the Maastricht process, the former mainly stipulating wage moderation on the basis of a low target inflation rate, the latter introducing important elements of labor market flexibility.

Patto sociale per lo sviluppo e l'occupazione (Social Pact for Growth and Employment) was signed in December 1998 in a similar spirit, establishing an environment for tripartite (Unions, Employers, Government) discussion of all employment-related contractual, fiscal, and investment issues. It focuses on the new EMU policy environment and mentions explicitly the Luxembourg process, in particular its focus on social-partner dialogue. It covers all sectors and regions, but envisions increased participation of local governments (not only Regions, but also smaller units) in the discussion. Discussions are carried out on annual cycles, with an evaluation in the Spring of specific programs and overall progress. Tripartite working groups are tasked with (i) assessing incentive systems and propose their adaptation; (ii) simplify procedures of authorization for incentives, infrastructures, new establishments; (iii) evaluate existing employment related instruments, particularly as regards "emersione" (tax holidays for formerly illegal employment relationships) and "lavori socialmente utili" (subsidized public employment); (iv) coordinate different levels of government so as to improve EU Structural Funds use.

At the overall level, Pacts stipulate a number of education and training-related measures on the part of the Government, as well as a redesign of fiscal and contributory schemes aimed at reducing labor costs. In exchange, Unions agree to index contractual wage profiles to planned inflation rates (with only partial ex-post recouping of lost purchasing power). This provision played a crucial role in allowing entry in EMU. 
Figure 1. Unemployment Rate in Italy. Historical Series 1955-1998

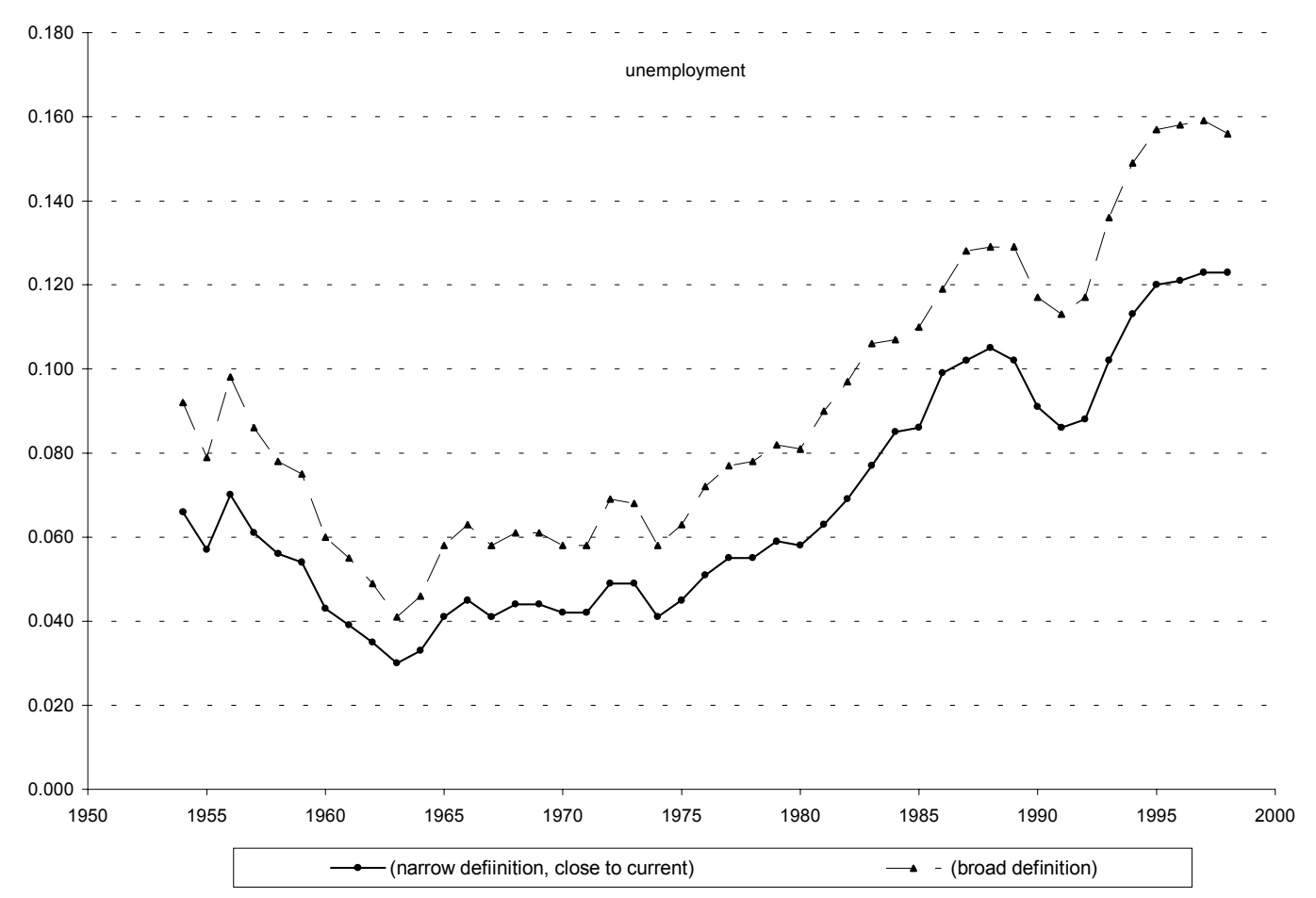

Source: Paola Casavola (Bank of Italy) 
Figure 2: Total Unemployment Rate and GDP growth in Italy: 1977-2001.

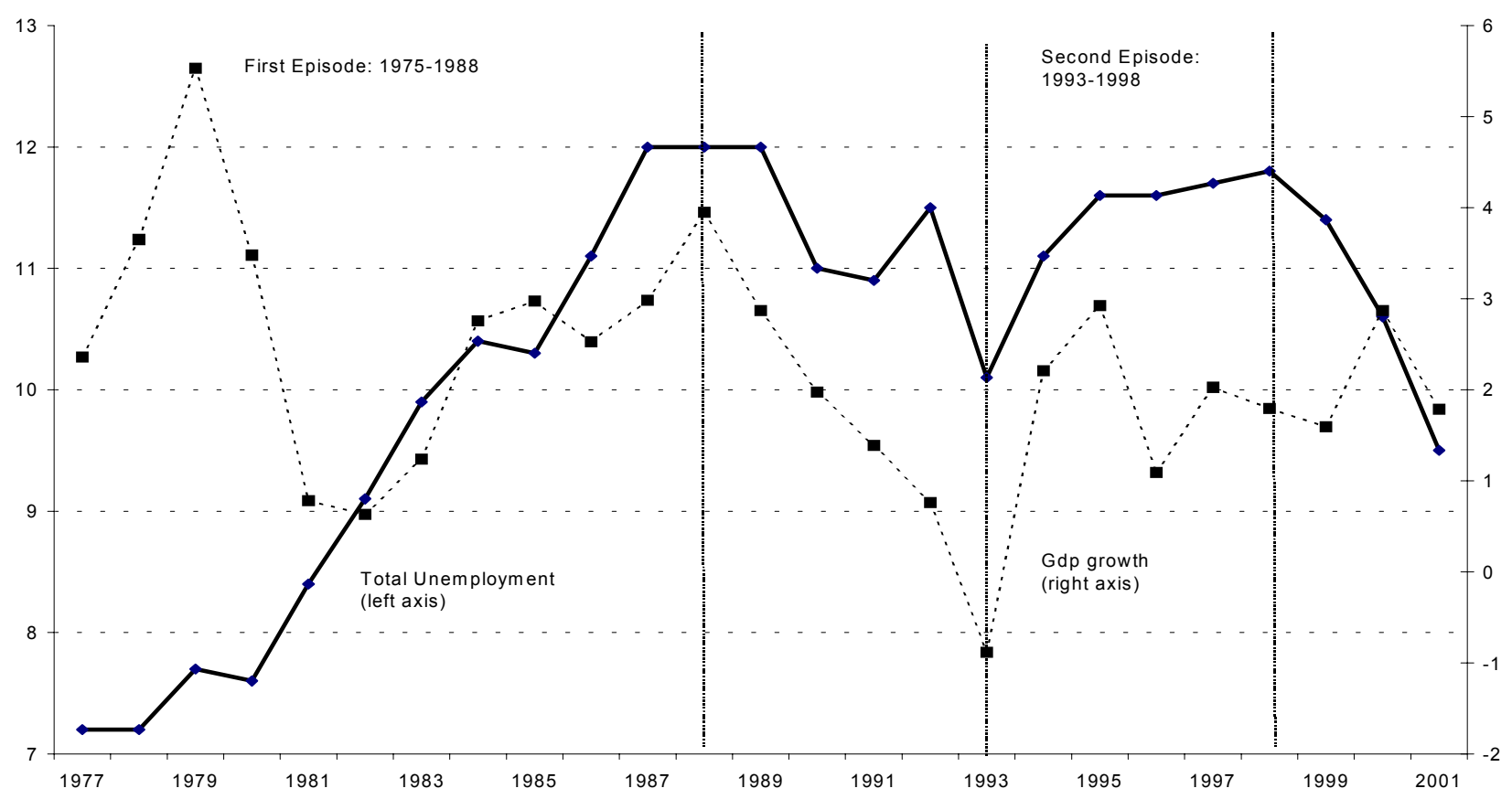

Source: Istat and Bank of Italy 
Figure 3. Regional Male Unemployment: 1977-2001

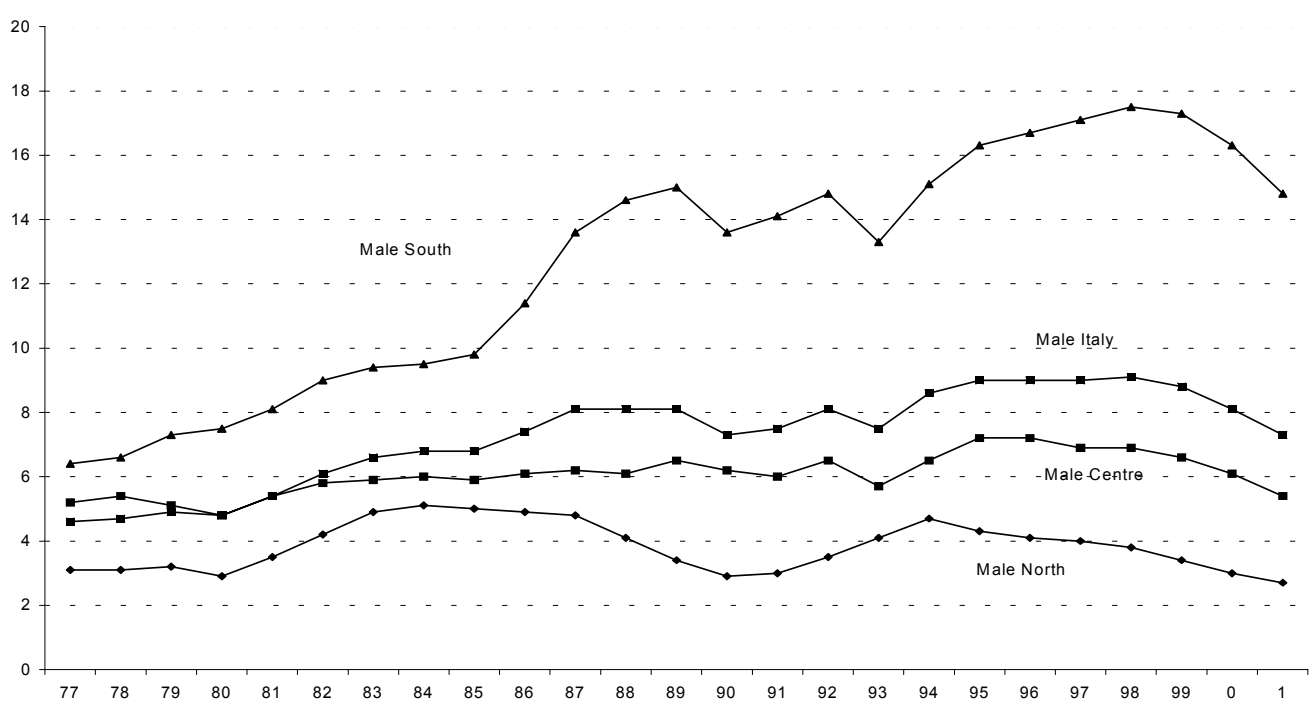

Source: Istat and Bank of Italy 
Figure 4. Regional Female Unemployment: 1977-2001

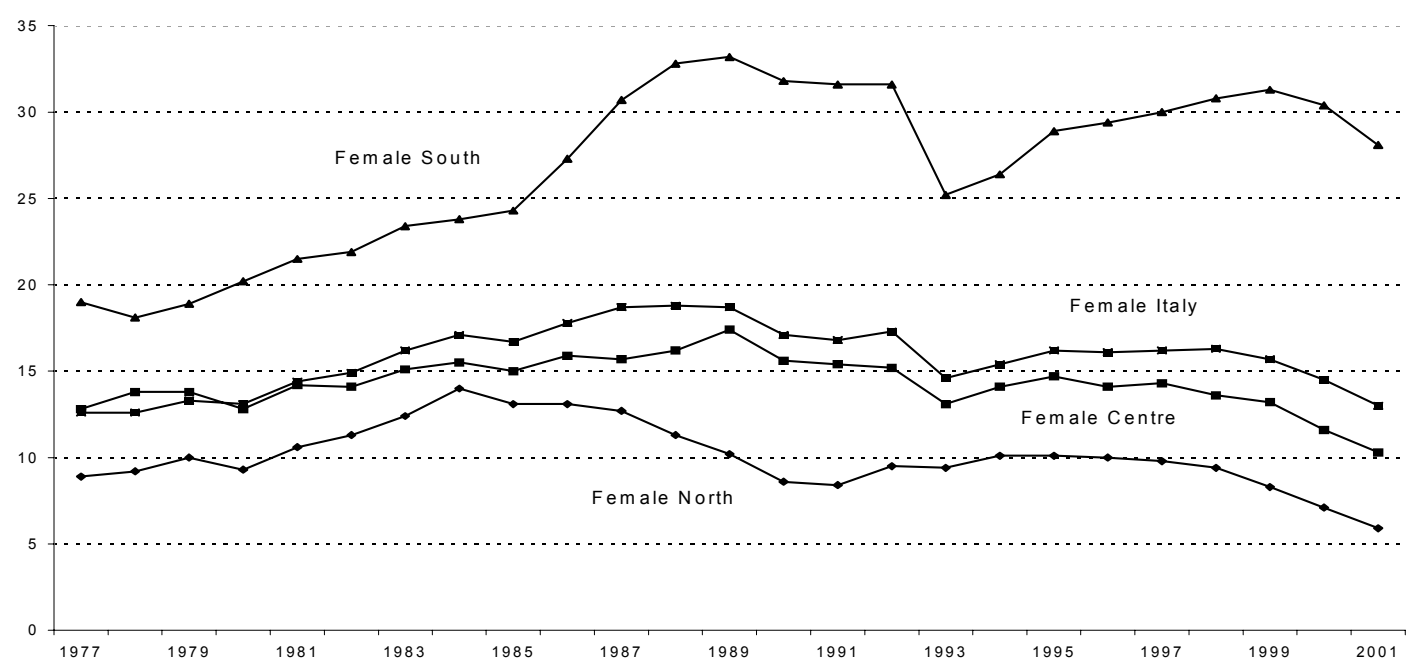

Source: Istat and Bank of Italy 
Figure 5. Shares of Unemployment by Age Groups



Source: database compiled by Bertola, Blau, Kahn (2002) from National-source data reported in $O E C D$ Labor force statistics, various issues.

Figure 6: Shadow Employment Rate by Italian Regions: Average 1995-1999

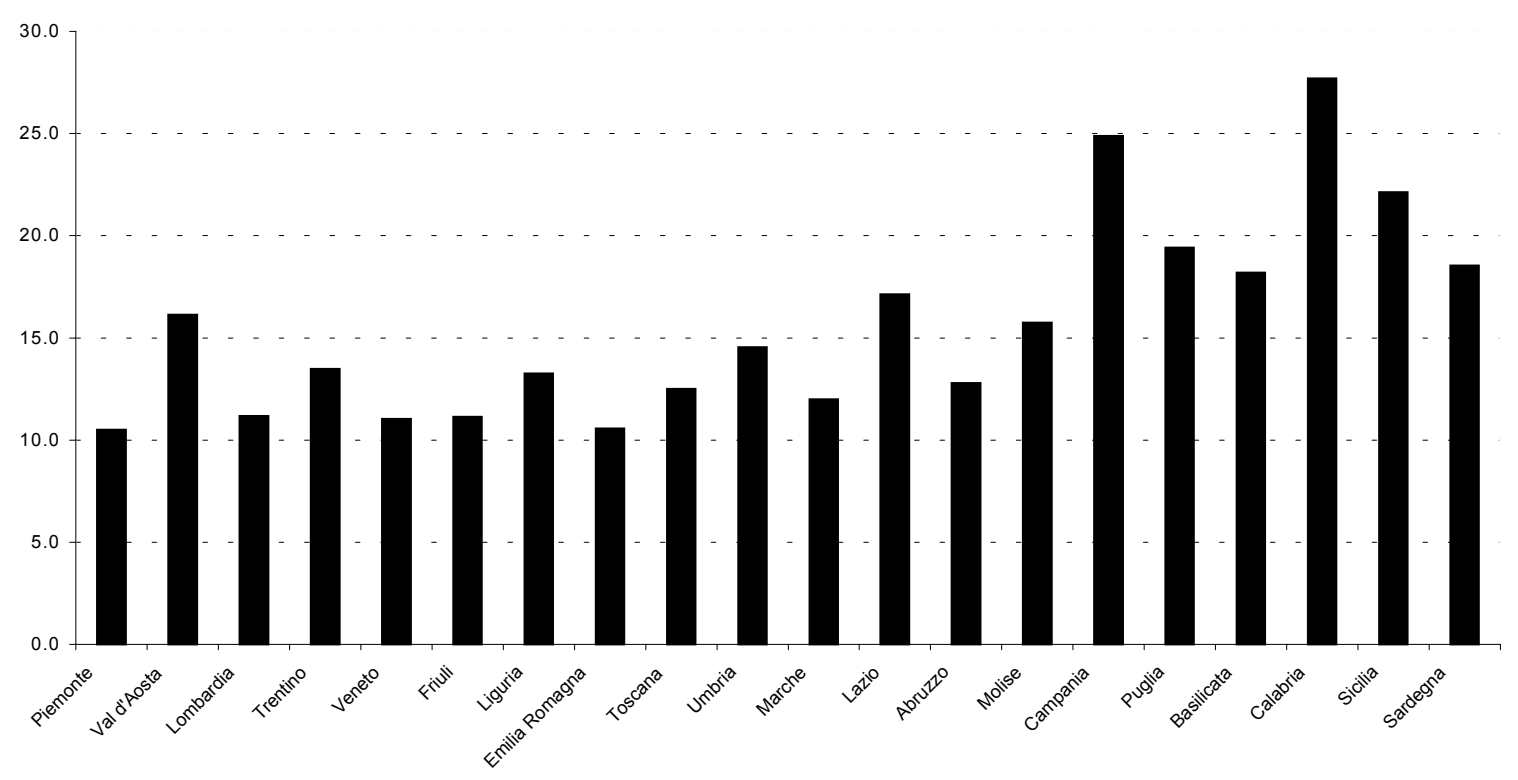

Source: Boeri and Garibaldi (2002) 
Figure 7. Percentile earnings differentials, Italy

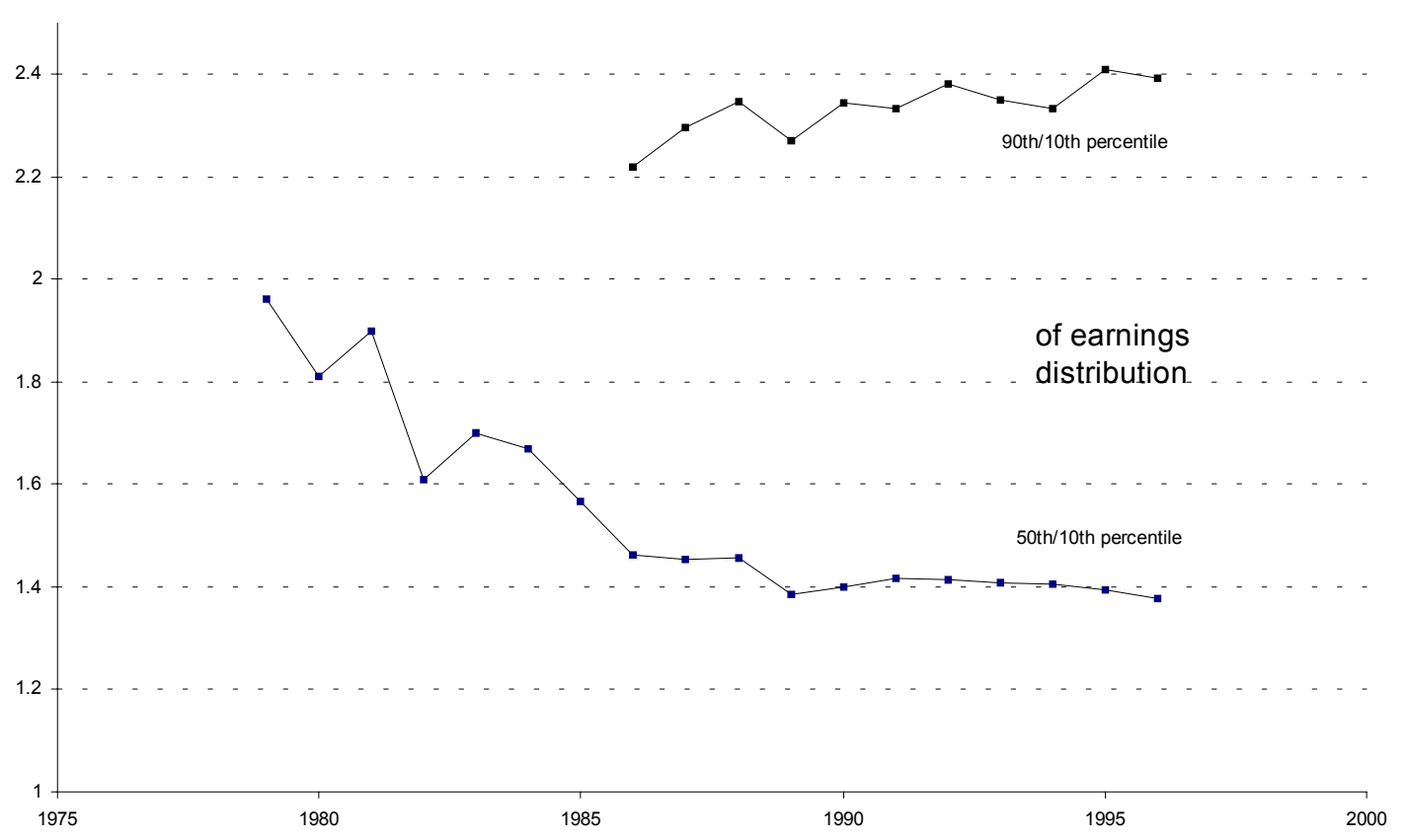

Source: OECD.

Figure 8: Union membership and strike activity over time

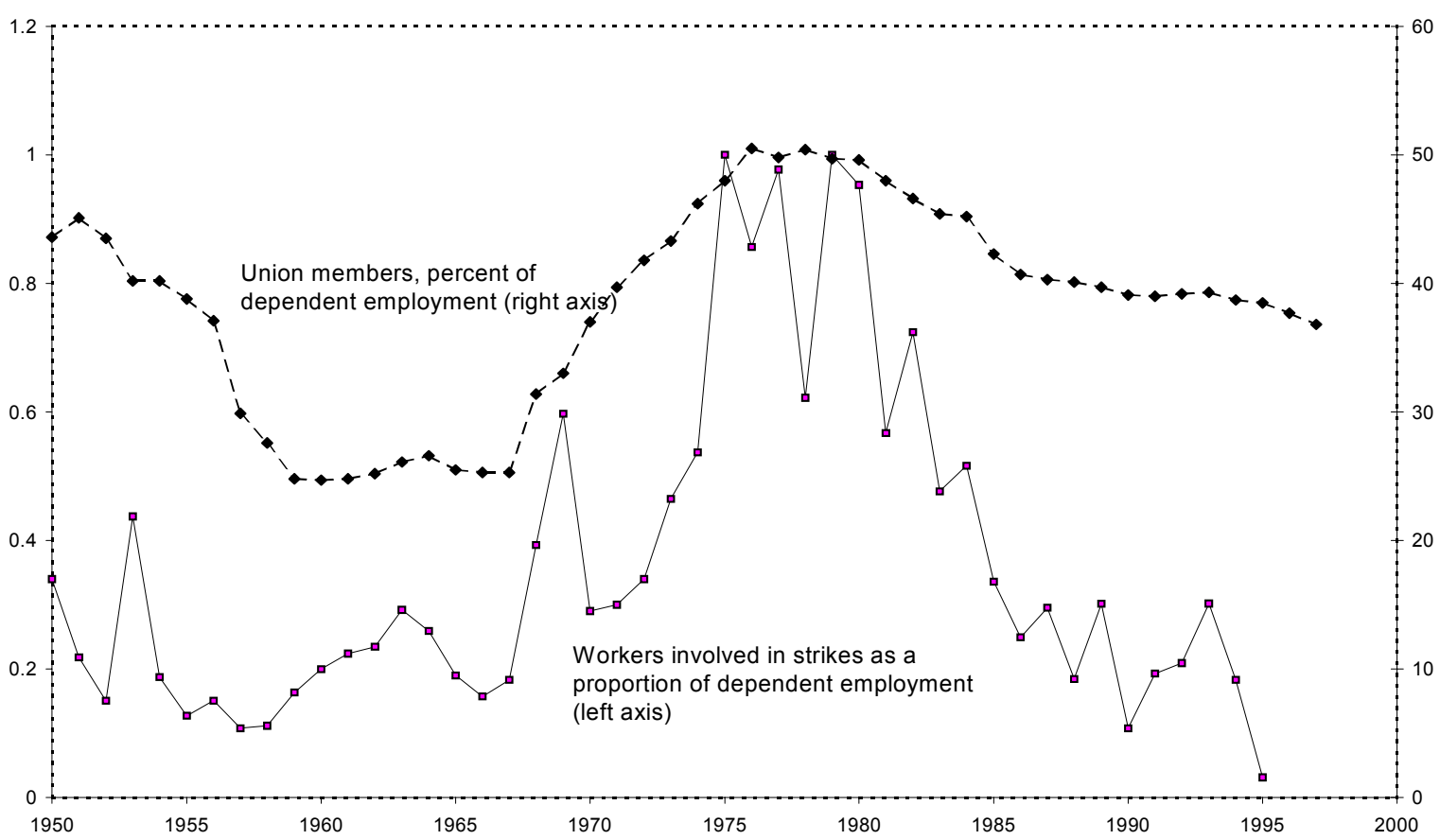

Source: Kindly made available by Checchi and Lucifora (2002), see that paper for details of definition and original data sources. 
Figure 9: Dynamics of government influences on the labor market

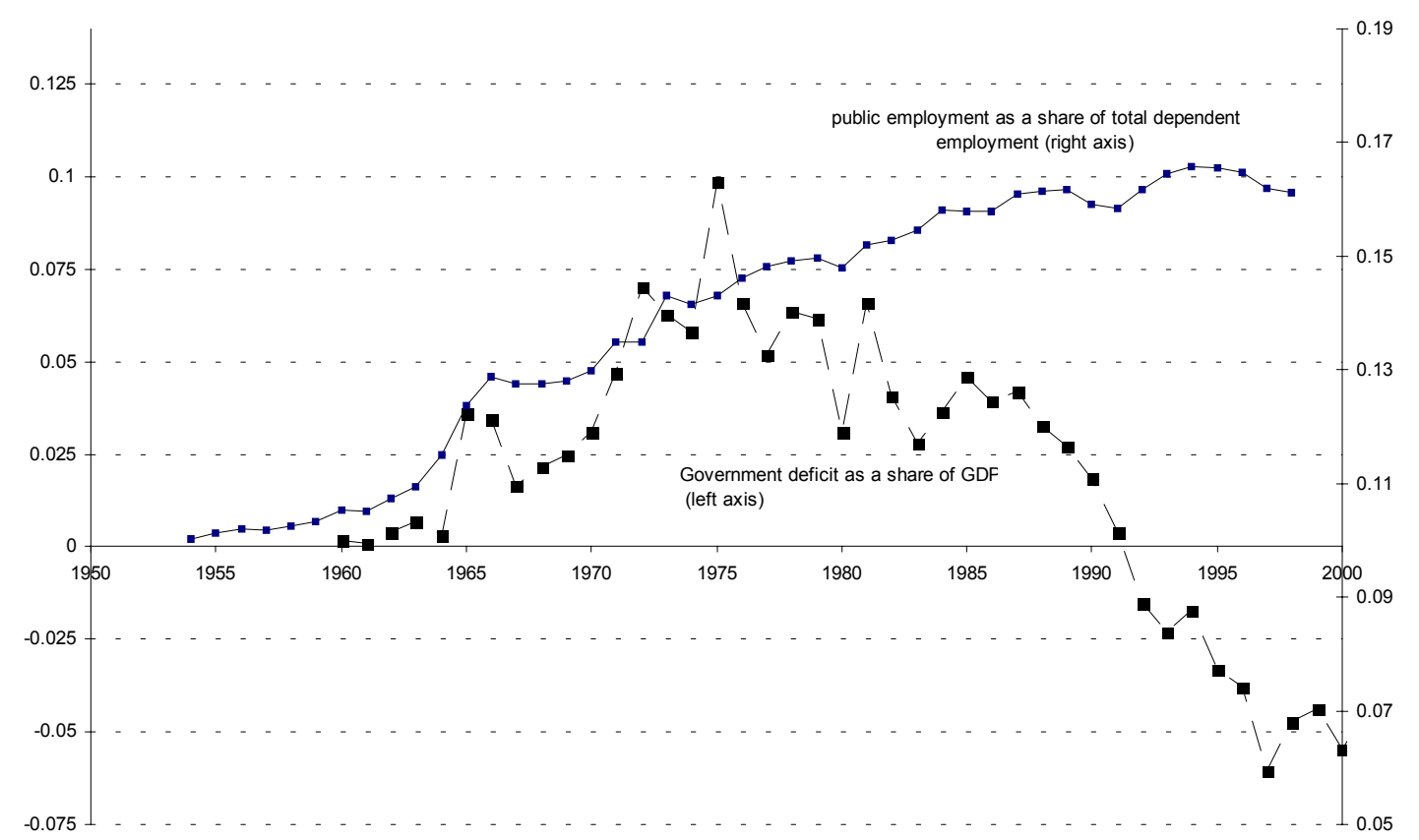

Source: see Checchi and Lucifora (2002) for public employment, OECD for primary deficit.

Figure 10: Inflation Rate: 1969-2000

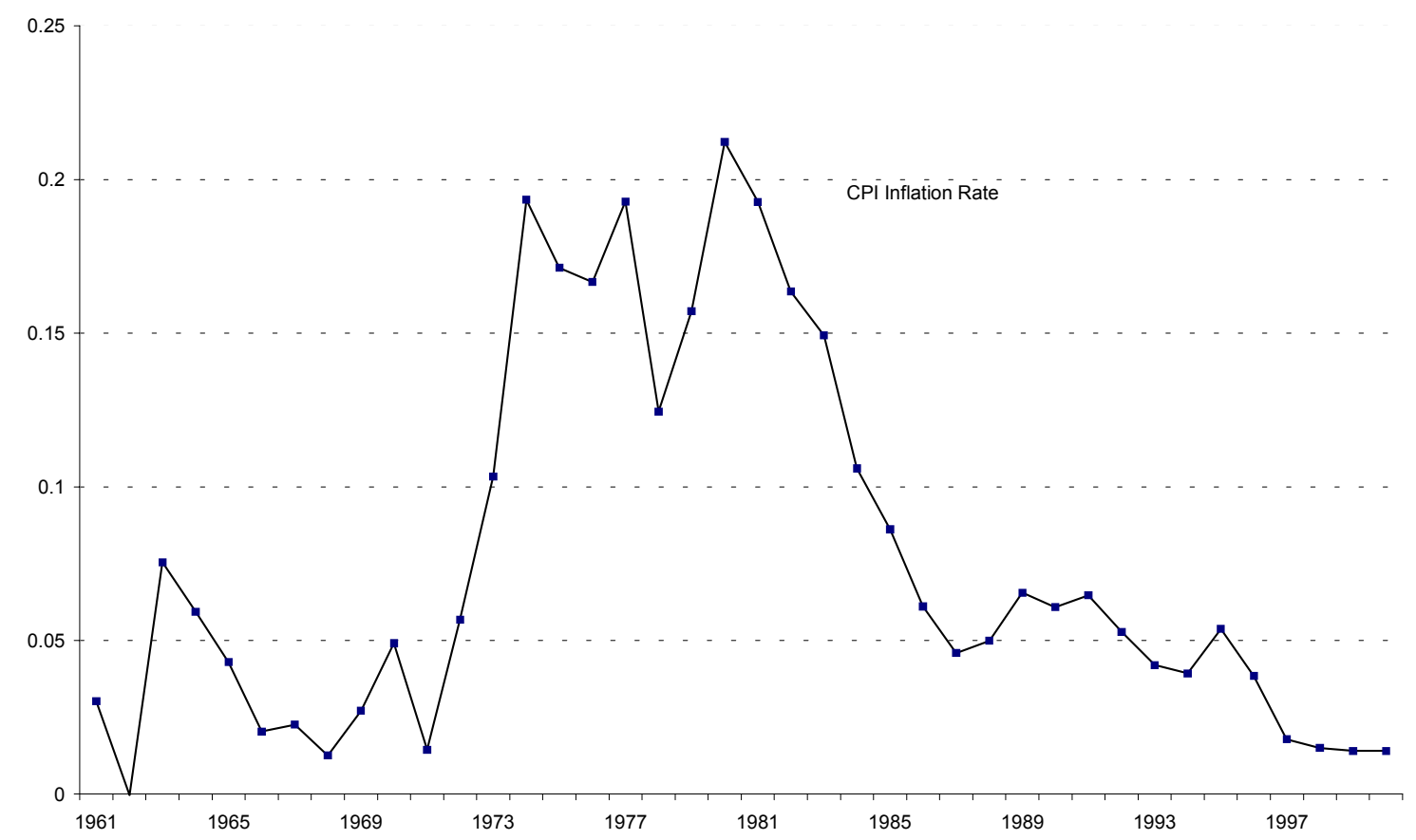

Source: OECD 
Fig 12: Social Security Revenues as a Share of GDP: 1969-2000

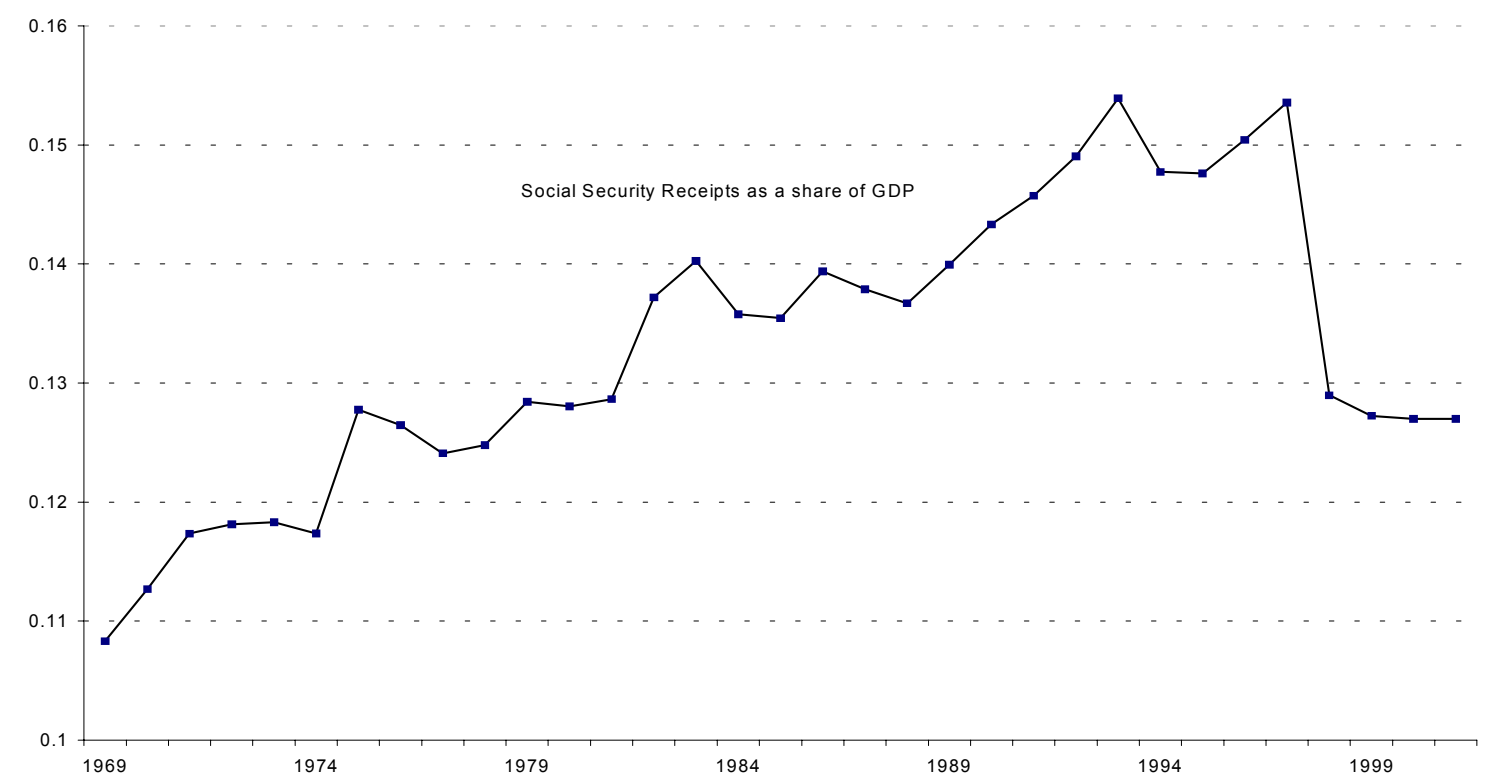

Source: OECD 
Table 1. Structure of Unemployment in Italy. 2002

\begin{tabular}{|c|c|c|c|}
\hline & $\begin{array}{l}\text { Percentage } \\
\text { of Labor Force }\end{array}$ & Thousands & Shares $\backslash 1$ \\
\hline All & 8.70 & 2096 & 1.00 \\
\hline Male & 6.70 & 1107 & 0.53 \\
\hline Female & 11.70 & 988 & 0.47 \\
\hline \multicolumn{4}{|l|}{ Regional } \\
\hline North & 4.00 & 467 & 0.22 \\
\hline Centre & 6.60 & 311 & 0.14 \\
\hline South & 18.20 & 1384 & 0.64 \\
\hline Youth $\backslash 2$ & 26.10 & 852 & 0.41 \\
\hline Male & 23.00 & 426 & 0.20 \\
\hline Female & 30.30 & 426 & 0.20 \\
\hline
\end{tabular}

Source: Istat

$\backslash 1$ With respect to the total number of unemployed

12 Refer to first time unemployed

Table 2 Labour Force Participation Rates by Region, Age and Gender. 1991-2001 average

\begin{tabular}{lrrr}
\hline & Total & Male & Female \\
\hline Italy & 46.7 & 60.59 & 33.83 \\
by Region & & & \\
$\quad$ North & 49.71 & 61.98 & 38.34 \\
Centre & 47.1 & 59.91 & 35.3 \\
South & 42.63 & 59.12 & 27.14 \\
by Age & & & \\
$15-24$ & 38.5 & 42.06 & 38.5 \\
$25-39$ & 76.07 & 90.9 & 76.07 \\
$40-59$ & 62.67 & 83.79 & 62.67 \\
& & & \\
\hline
\end{tabular}

Source: Istat 
Table 3. Unemployment Rates by Age, Regions and Educational Attainment

\begin{tabular}{llrrrr}
\hline Age Group & Highest Degree & North West & North East & Centre & South \\
\hline $25-24$ & & & & \\
& University Degree and Phd & 5.6 & 7.9 & 14.1 & 28 \\
& High School Diploma & 3.8 & 3.6 & 9.8 & 27.3 \\
& Professional Diploma & 4.1 & 3.2 & 8.3 & 26.6 \\
& Secondary Degree & 5.9 & 4 & 10.5 & 24.7 \\
& Primary Degree & 11 & 5.8 & 14.5 & 35.6 \\
& Total & 5 & 4.3 & 10.6 & 26.8 \\
& & & & \\
& University Degree and Phd & & & 2 & 2.3 \\
& High School Diploma & 1.1 & 1.3 & 3 & 6.3 \\
& Professional Diploma & 1.8 & 2 & 3.6 & 9.9 \\
& Secondary Degree & 2.5 & 2.4 & 4.7 & 12.3 \\
& Primary Degree & 3.6 & 2.7 & 5.8 & 16.3 \\
& Total & 3.9 & 2.9 & 3.9 & 10 \\
& Total & 2.7 & 2.4 & & \\
& University Degree and Phd & & & & 9.7 \\
& High School Diploma & 2.7 & 3.7 & 5.6 & 14.4 \\
& Professional Diploma & 2.6 & 2.7 & 5.6 & 15.1 \\
Secondary Degree & 3.1 & 2.7 & 5.2 & 16.6 \\
& Primary Degree & 3.4 & 3.1 & 6.6 & 18.6 \\
Total & 4.4 & 3.1 & 6.4 & 6.3 \\
\hline
\end{tabular}

Source: Istat

Table 4. Unemployment Rates by Macro Region and Gender, 1977-2001

\begin{tabular}{rrrrrr}
\hline & Average & Maximum & Minimum & Time Trend & t-statistic \\
\hline Italy & & & & & \\
Male & 7.26 & 9.1 & 4.6 & 0.17 & 8.22 \\
Female & 15.76 & 18.8 & 12.6 & 0.05 & 1.14 \\
North & & & & 0 & 0.3 \\
Male & 3.82 & 5.1 & 2.7 & -0.08 & -0.38 \\
Female & 10.1 & 14 & 5.9 & -0.12 & -2.59 \\
Centre & & & & & \\
Male & 6.06 & 7.2 & 4.8 & 0.05 & 4.41 \\
Female & 14.3 & 17.4 & 10.3 & -0.05 & -1.34 \\
South & & & & & \\
Male & 12.6 & 17.5 & 6.4 & 0.47 & 13.13 \\
Female & 26.82 & 33.2 & 18.1 & 0.49 & 5.59 \\
\hline
\end{tabular}

Source: Istat and authors' calculation 
Table 5. Unemployment Rates by Age and Gender, 1977-2001

\begin{tabular}{rrrrrr}
\hline & Average & Maximum & Minimum & Time Trend t-statistic \\
\hline Italy & & & & & \\
Male & 7.26 & 9.1 & 4.6 & 0.17 & 8.22 \\
Female & 15.76 & 18.8 & 12.6 & 0.05 & 1.14 \\
$15-24 \quad$ Male & 26.62 & 29.9 & 20.4 & 0.29 & 4.7 \\
Female & 36.71 & 42.2 & 28.2 & 0.2 & 1.97 \\
$25-39$ & & & & & \\
Male & 6.24 & 9.5 & 2.4 & 0.31 & 16 \\
Female & 14.15 & 17.9 & 8.7 & 0.33 & 6.24 \\
$40-59$ & & & & & \\
Male & 2.48 & 4.2 & 1 & 0.13 & 13.25 \\
Female & 5.84 & 7.4 & 4.2 & 0.11 & 9.54 \\
\hline
\end{tabular}

Source: Istat and authors' calculation

Table 6. Contribution to Cumulative Change in Unemployment by Age Groups: 1978-1997

As a Percentage of Total Change in Unemployment

\begin{tabular}{|c|c|c|}
\hline Age Group & Male & Female \\
\hline 14-19 & -6.98 & -9.97 \\
\hline $20-24$ & 13.78 & 20.55 \\
\hline $25-29$ & 21.15 & 22.28 \\
\hline $30-39$ & 12.47 & 14.87 \\
\hline $40-49$ & 4.85 & 5.41 \\
\hline $50-59$ & 5.19 & 2.79 \\
\hline $60-64$ & 3.78 & -0.01 \\
\hline $65+$ & -4.68 & -4.43 \\
\hline Total & 49.56 & 51.48 \\
\hline
\end{tabular}

Source: Author's Calculation on ILO data. 


\title{
CESifo Working Paper Series
}

\author{
(for full list see www.cesifo.de)
}

841 Robert Fenge and Martin Werding, Ageing and the Tax Implied in Public Pension Schemes: Simulations for Selected OECD Countries, January 2003

842 Robert Fenge and Martin Werding, Ageing and Fiscal Imbalances Across Generations: Concepts of Measurement, January 2003

843 Giovanni Andrea Cornia, The Impact of Liberalisation and Globalisation on Income Inequality in Developing and Transitional Economies, January 2003

844 Peter Fredriksson and Per Johansson, Program Evaluation and Random Program Starts, January 2003

845 Bernd Hayo and Matthias Wrede, Fiscal Equalisation: Principles and an Application to the European Union, January 2003

846 Syed M. Ahsan and Jaideep Oberoi, Inequality, Well-being and Institutions in Latin America and the Caribbean, January 2003

847 Chang Woon Nam and Doina Maria Radulescu, The Role of Tax Depreciation for Investment Decisions: A Comparison of European Transition Countries, January 2003

848 V. Bhaskar and Steinar Holden, Wage Differentiation via Subsidised General Training, January 2003

849 Paloma Lopez-Garcia, Labour Market Performance and Start-up Costs: OECD Evidence, January 2003

850 Christian Keuschnigg and Soren Bo Nielsen, Public Policy for Start-up Entrepreneurship with Venture Capital and Bank Finance, January 2003

851 Yin-Wong Cheung, Menzie D. Chinn, and Eiji Fujii, China, Hong Kong, and Taiwan: A Quantitative Assessment of Real and Financial Integration, January 2003

852 Gregory D. Hess, The Economic Welfare Cost of Conflict: An Empirical Assessment, February 2003

853 Douglas J. Cumming and Jeffrey G. MacIntosh, Comparative Venture Capital Governance. Private versus Labour Sponsored Venture Capital Funds, February 2003

854 Eckhard Janeba and John Douglas Wilson, Decentralization and International Tax Competition, February 2003

855 Tapio Palokangas, Capital Accumulation and Employment Cycles in a Model of Creative Destruction, February 2003 
856 Brendan Walsh, When Unemployment Disappears: Ireland in the 1990s, February 2003

857 Luis H. R. Alvarez and Erkki Koskela, A General Approach to the Stochastic Rotation Problem with Amenity Valuation, February 2003

858 Christian Schultz, Strategic Campaigns and Redistributive Politics, February 2003

859 Ernst Fehr and Joseph Henrich, Is Strong Reciprocity a Maladaptation? On the Evolutionary Foundations of Human Altruism, February 2003

860 Haizhou Huang, Dalia Marin, and Chenggang Xu, Financial Crisis, Economic Recovery and Banking Development in Former Soviet Union Economies, February 2003

861 Pedro Cardoso and Bernard M.S. van Praag, How Sustainable Are Old-age Pensions in a Shrinking Population with Endogenous Labour Supply?, February 2003

862 Volker Meier, Efficient Transfer of Aging Provisions in Private Health Insurance, February 2003

863 Edward Castronova, Theory of the Avatar, February 2003

864 Robert S. Chirinko, Hans van Ees, Harry Garretsen, and Elmer Sterken, Investor Protections and Concentrated Ownership: Assessing Corporate Control Mechanisms in the Netherlands, February 2003

865 Bernard M.S. van Praag and Pedro Cardoso, The Mix Between Pay-as-you-go and Funded Pensions and what Demography has to do with it, February 2003

866 Ernst Fehr, Urs Fischbacher, Bernhard von Rosenbladt, Jürgen Schupp, and Gert G. Wagner, A Nation-Wide Laboratory. Examining Trust and Trustworthiness by Integrating Behavioral Experiments into Representative Survey, February 2003

867 Frank Heinemann, The Inflationary Impact of Wage Indexation, February 2003

868 Eytan Sheshinski, Bounded Rationality and Socially Optimal Limits on Choice in a Self-Selection Model, February 2003

869 M. Hashem Pesaran, Estimation and Inference in Large Heterogenous Panels with Cross Section Dependence, February 2003

870 Luis H. R. Alvarez and Erkki Koskela, On the Tree-Cutting Problem under Interest Rate and Forest Value Uncertainty, February 2003

871 Norbert Berthold and Rainer Fehn, Unemployment in Germany: Reasons and Remedies, February 2003

872 Clemens Fuest, Bernd Huber, and Philipp Tilleßen, Tax Policy and Entrepreneurship in the Presence of Asymmetric Information in Capital Markets, February 2003

873 Eytan Sheshinski, Optimum and Risk-Class Pricing of Annuities, February 2003 
874 Willi Leibfritz, Paul O'Brien and Jean-Christophe Dumont, Effects of Immigration on Labour Markets and Government Budgets - An Overview, February 2003

875 M. Hashem Pesaran and Allan Timmermann, How Costly is it to Ignore Breaks when Forecasting the Direction of a Time Series?, February 2003

876 Thorvaldur Gylfason and Gylfi Zoega, Education, Social Equality and Economic Growth: A View of the Landscape, February 2003

877 Robin Boadway and Jean-François Tremblay, Public Economics and Startup Entrepreneurs, February 2003

878 Erkki Koskela and Roope Uusitalo, The Un-Intended Convergence: How the Finnish Unemployment Reached the European Level, February 2003

879 Robert Fenge and Volker Meier, Pensions and Fertility Incentives, February 2003

880 Eytan Sheshinski, Note on Income Taxation and Occupational Choice, February 2003

881 A B Atkinson, Income Inequality in OECD Countries: Data and Explanations, February 2003

882 Thomas Gehrig and Rune Stenbacka, Venture Cycles: Theory and Evidence, February 2003

883 Ralf Becker and Thomas Hellmann, The Genesis of Venture Capital - Lessons from the German Experience, March 2003

884 Eytan Sheshinski, Note on the Optimum Pricing of Annuities, March 2003

885 Paul De Grauwe and Magdalena Polan, Globalisation and Social Spending, March 2003

886 F. van der Ploeg, Do Social Policies Harm Employment and Growth?, March 2003

887 Mirjam van Praag, Initial Capital Constraints Hinder Entrepreneurial Venture Performance: An empirical analysis, March 2003

888 Bernard Steunenberg, Coordinating Sectoral Policymaking: Searching for Countervailing Mechanisms in the EU Legislative Process, March 2003

889 Eytan Sheshinski, Optimum Delayed Retirement Credit, March 2003

890 Frederick van der Ploeg, Rolling Back the Public Sector - Differential effects on employment, investment and growth, March 2003

891 Paul De Grauwe and Marc-Alexandre Sénégas, Monetary Policy in EMU when the Transmission is Asymmetric and Uncertain, March 2003

892 Steffen Huck and Kai A. Konrad, Strategic Trade Policy and the Home Bias in Firm Ownership Structure, March 2003 
893 Harry Flam, Turkey and the EU: Politics and Economics of Accession, March 2003

894 Mathias Hoffmann and Ronald MacDonald, A Re-examination of the Link between Real Exchange Rates and Real Interest Rate Differentials, March 2003

895 Badi H. Baltagi, Espen Bratberg, and Tor Helge Holmås, A Panel Data Study of Physicians' Labor Supply: The Case of Norway, March 2003

896 Dennis C. Mueller, Rights and Citizenship in the European Union, March 2003

897 Jeremy Edwards, Gains from Trade in Tax Revenue and the Efficiency Case for Trade Taxes, March 2003

898 Rainer Fehn and Thomas Fuchs, Capital Market Institutions and Venture Capital: Do They Affect Unemployment and Labour Demand?, March 2003

899 Ronald MacDonald and Cezary Wójcik, Catching Up: The Role of Demand, Supply and Regulated Price Effects on the Real Exchange Rates of Four Accession Countries, March 2003

900 R. Selten, M. Schreckenberg, T. Pitz, T. Chmura, and S. Kube, Experiments and Simulations on Day-to-Day Route Choice-Behaviour, April 2003

901 Stergios Skaperdas, Restraining the Genuine Homo Economicus: Why the Economy Cannot be Divorced from its Governance, April 2003

902 Yin-Wong Cheung, Menzie D. Chinn, and Antonio Garcia Pascual, What Do We Know about Recent Exchange Rate Models? In-Sample Fit and Out-of-Sample Performance Evaluated, April 2003

903 Mika Widgrén, Enlargements and the Principles of Designing EU - Decision-Making Procedures, April 2003

904 Phornchanok Cumperayot, Dusting off the Perception of Risk and Returns in FOREX Markets, April 2003

905 Kai A Konrad, Inverse Campaigning, April 2003

906 Lars P. Feld and Stefan Voigt, Economic Growth and Judicial Independence: Cross Country Evidence Using a New Set of Indicators, April 2003

907 Giuseppe Bertola and Pietro Garibaldi, The Structure and History of Italian Unemployment, April 2003 